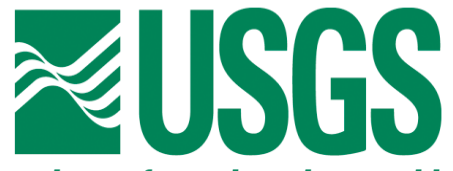

science for a changing world

\title{
Soil Organic Carbon on Lands of the Department of the Interior
}

\author{
By Norman B. Bliss
}

Any use of trade, product, or firm names is for descriptive purposes only and does not imply endorsement by the U.S. Government.

Open-File Report 03-304

U.S. Department of the Interior U.S. Geological Survey 


\title{
Soil Organic Carbon on Lands of the Department of the Interior
}

\author{
Norman B. Bliss ${ }^{1}$
}

${ }^{1}$ USGS EROS Data Center, SAIC, Sioux Falls, SD 57198 (Work performed under U.S. Geological Survey contracts 1434-CR-97-CN-40274 and 03CRCN0001) bliss@usgs.gov

\begin{abstract}
The stocks of soil organic carbon (SOC) on the landscape are an important element in the global carbon cycle. Changes in soil carbon can change the concentrations of greenhouse gases in the atmosphere. If carbon dioxide from the atmosphere, captured through photosynthesis, is ultimately stored in the soil to an enhanced degree, the resulting soil carbon sequestration may help delay some of the undesirable consequences of global warming. If the conditions affecting the balance of photosynthesis and decomposition are changed to favor decomposition, then soil carbon can be released to the atmosphere as carbon dioxide or methane, contributing to greenhouse warming.

The Department of the Interior (DOI) is the largest land management agency in the United States, with jurisdiction influencing more than 2 million square kilometers of land--about 22 percent of the total land area of the country. Estimates using available data indicate that the DOI lands have nearly 18 petagrams ( $\mathrm{Pg} ; 1 \mathrm{Pg}=10^{15} \mathrm{~g}=1$ gigaton) of SOC, which is about 22 percent of the estimate for the country $(81 \mathrm{Pg})$. The distribution is not uniform, and few areas of DOI lands reflect "average" conditions. Large areas of land with low biological productivity occur in the conterminous U.S. part of the DOI lands, and substantial areas with high SOC occur in Alaska. About 74 percent of the SOC on DOI lands is in Alaska. Details on amounts of SOC by DOI Bureau and location are shown in a series of tables and maps. For the conterminous United States, statistics are given by land cover type and soil depth ranges.
\end{abstract}

\section{Introduction}

Soil organic carbon (SOC) develops over time from the partially decomposed tissues of plants and animals. The amount present at any site is determined by the balance between inputs to the soil that originate with photosynthesis and the processes that decompose the organic matter. The rates of these processes depend on the local environmental conditions, particularly soil wetness, soil texture, temperature, and nutrients. In undisturbed conditions, a steady state of soil carbon may develop, in which the input and decomposition rates are balanced.

In hot arid areas, photosynthetic inputs are low and decomposition rates are high, resulting in little accumulation of soil carbon (Stewart, 1995). In wet cold soils, the rates of photosynthesis may be low, but decomposition rates are even lower, so there may be large amounts of SOC that accumulate in wetlands or peat bogs (Kolchugina and others, 1995; Lal and Kimble, 2000; Rabenhorst, 1995; Mitsch and Wu, 1995). Most landscapes in the United States are intermediate between these extremes.

The organic matter in soils, measured as SOC, is important for maintaining soil fertility and 
controlling water movement into and through the soil (Seybold and others, 1998; Herrick and Wander, 1998). There is a growing need to better understand changes of SOC on the landscape and how such changes influence the net flux of carbon to or from the atmosphere. If decomposition exceeds inputs, carbon is released to the atmosphere. Usually this is as carbon dioxide, but in wet conditions without oxygen, methane is formed. These are both greenhouse gases and contribute to global warming.

\subsection{Land Management and Soil Carbon}

Some land use changes, such as converting grassland to agriculture or removing forests, tend to release SOC to the atmosphere (Janzen and others, 1998). Other changes, such as restoring degraded lands, may lead to a sequestration (new storage) of carbon from the atmosphere into the soil (Paustian and others, 1998). Changes in land management practices may also influence the sequestration or release of soil carbon. On rangeland, livestock densities that maintain healthy grasses may maintain SOC levels. On agricultural land, reduced tillage or no-till tends to enhance the retention of SOC (Donigian and others, 1995).

\subsection{Possible feedbacks}

Many conditions that influence photosynthesis and decomposition rates could influence soil carbon sequestration (Lal and others, 1995). Examples of factors that may increase sequestration include fertilization with carbon dioxide and nitrogen, creating or restoring wetlands, and decreasing the density of grazing livestock. Factors that may release carbon to the atmosphere include draining wetlands, overgrazing, and fires. Some activities, such as fire suppression, have complex consequences in time and space: initially carbon may be sequestered in biomass, but increased fire fuels may lead to a sudden release by wildfire. The dynamics of SOC following fire are very complex, and rates of change of SOC before and after the fire may be quite different.

Some factors, such as climate change, can create self-reinforcing feedbacks through effects on SOC storage. For example, warming Arctic soils may dry out and release greenhouse gases, leading to additional warming and drying, and creating a positive feedback in a location where land is not intensively managed (Oechel and others, 1993). A negative feedback is also possible in the Arctic, in which plant community changes could increase photosynthesis and lead to more carbon storage (Oechel and others, 2000).

\subsection{Scope of this paper}

This paper provides an overview of the distribution of SOC on the lands of the Department of the Interior (DOI). It makes use of existing databases. It should be useful as a guide to locations where additional research would lead to a better accounting for carbon budgets. The estimates presented in this paper could be improved with additional data sources, such as detailed soil maps linked to site-specific soil measurements, especially if developed within a more comprehensive research framework that evaluates local and regional processes, as well as the patterns of SOC distribution presented here. 


\section{Methods}

The SOC maps were developed using the State Soil Geographic Database (STATSGO), from the Department of Agriculture's Natural Resources Conservation Service (NRCS, 1994). The SOC calculations follow the methods of Bliss and others (1995). The STATSGO data were intersected with data on Federal land boundaries from the National Atlas (U.S. Geological Survey, 2000). Water areas were excluded if either STATSGO or the Federal lands datasets indicated a water area. Soil carbon was recalculated using site-specific soil data for the North Slope of Alaska, because insufficient data were available for that area at the time that the STATSGO data were developed (Bliss, Ping, Waltman and Michaelson, unpub. data, 2003).

For the conterminous United States, the National Land Characterization Dataset (NLCD; http://landcover.usgs.gov/natllandcover.html), with a nominal date of 1992, was used to characterize land cover for each 1-square-kilometer grid cell. The 21 classes of the NLCD were aggregated into 5 classes, and the dominant generalized class was used to characterize the cell. For the DOI lands, the SOC was separately mapped for each of the five generalized land cover classes.

\subsection{Carbon calculations in STATSGO}

Details of the SOC calculation using the STATSGO data are given in appendix A. The carbon content in each volume of soil is aggregated to give a measure of the mass per unit area, as shown on the maps. Multiplying by the area of the map units, we can calculate the total carbon for a study area.

\subsection{Modification of STATSGO for the North Slope of Alaska}

During previous work to develop a soil carbon map of North America, expert reviewers indicated that the SOC estimates for the North Slope of Alaska seemed too low. Six STATSGO map units, accounting for much of the Brooks Range, the foothills, and the coastal plain, have been recalculated by linking site-specific soil characterization data to the STATSGO map units (Bliss, Ping, Waltman, and Michaelson, unpub. data, 2003). The site-specific soil characterization data are often referred to as "pedon" data, because a pedon is the volume of soil sampled in the field in order to represent the natural soil unit at the site. A combination of published data (see Michaelson and others, 1996; NRCS Soil Survey Staff, 1996) and unpublished data were used. The recomputation increased the estimates for soil carbon in this area from approximately $10 \mathrm{~kg}$ $\mathrm{m}^{-2}$ to $39 \mathrm{~kg} \mathrm{~m}^{-2}$. If the Brooks Range (rough mountainous land with low carbon intensities) was excluded, then the average soil carbon intensities increased from approximately $15 \mathrm{~kg} \mathrm{~m}^{-2}$ to 57 $\mathrm{kg} \mathrm{m}^{-2}$. The recalculation used 48 soil profiles. Although the recalculation represents a substantial improvement in the quality of the estimates, additional soil sampling should be done to increase confidence in the estimates.

\subsection{The Federal lands data}

The National Atlas of the United states provides a digital database for the Federal and Indian 
Lands of the United States (U.S. Geological Survey, 2000). A plot of the extent of these lands is

given in appendix B, figure B1. All maps in this paper are collected in appendix B. Figure B2 is a map of the DOI lands showing the jurisdiction of each Bureau.

\subsection{Overlay of STATSGO with Federal lands}

The Federal lands coverage was overlaid with the STATSGO data in a geographic information system. For the conterminous United States, a gridded version was used to maintain consistency with other concurrent research. The grid spacing is $1 \mathrm{~km}$. For Alaska, a vector overlay was done.

Both the STATSGO and Federal lands coverages had indicators of water areas, and they were not always consistent. The Federal lands coverage was digitized using 1:2,000,000-scale source materials, and STATSGO was digitized from 1:250,000-scale source materials. Thus, the STATSGO representation of water was generally more complete, but there were occasions when water bodies were included in the Federal coverage but not in STATSGO. For the purpose of the analysis presented here, water was excluded if present in either coverage.

\subsection{SOC by Federal ownership classes}

The weighted average carbon content $\left(\mathrm{g} \mathrm{C} \mathrm{m}^{-2}\right)$ for each STATSGO map unit was attached to the value attribute table of the combined spatial dataset, using the map unit identifier (MUID) as the relational key to link the tables. The total carbon for each unique combination of input layers was computed by multiplying the carbon content per unit area by the area. Statistics were computed and maps were plotted for a hierarchy of 10 classes of land ownership. The hierarchy has four levels: level 1 represents all land, level 2 separates the non-Federal and Federal land, level 3 separates the Federal land into non-DOI land and DOI land, and level 4 separates the DOI land according to the five land management Bureaus. Maps and statistics were generated for the conterminous United States and Alaska, both separately and combined. Only the combined maps are included in this paper.

\subsection{National Land Cover Data}

The DOI land in the conterminous United States was evaluated according to land cover type. A similar analysis is possible for the non-DOI lands but is not reported here.

The NLCD 1992 was developed by the classification of Landsat thematic mapper satellite image data, with extensive reference to aerial photographs, and tested with an accuracy assessment procedure (Vogelmann and others, 1998; NLCD, 2002). The NLCD classifies the land cover for the conterminous United States into 21 classes (see table 1). 
Table 1. Land cover classes used with the National Land Cover Data 1992, and codes for a generalization into five classes

\begin{tabular}{|c|c|c|c|}
\hline Land cover class name & Class code & $\begin{array}{c}\text { Generalized } \\
\text { code }\end{array}$ & $\begin{array}{c}\text { Area }^{\mathrm{a}} \text { in the } \\
\text { conterminous } \\
\text { United States }\left(\mathrm{km}^{2}\right)\end{array}$ \\
\hline Open Water & LC11 & G1 & 100,833 \\
\hline Perennial Ice/Snow & LC12 & G1 & 1,502 \\
\hline Low-Intensity Residential & LC21 & G1 & 79,828 \\
\hline High-Intensity Residential & LC22 & G1 & 20,240 \\
\hline Commercial/Industrial/Transportation & LC23 & G1 & 43,928 \\
\hline Bare Rock/Sand/Clay & LC31 & G1 & 108,334 \\
\hline Quarries/Strip Mines/Gravel Pits & LC32 & G1 & 6,612 \\
\hline Transitional & LC33 & G2 & 49,268 \\
\hline Deciduous Forest & LC41 & G2 & 924,615 \\
\hline Evergreen Forest & LC42 & G2 & 996,938 \\
\hline Mixed Forest & LC43 & G2 & 337,546 \\
\hline Shrubland & LC51 & G3 & $1,410,840$ \\
\hline Orchards/Vineyards/Other & LC61 & G4 & 16,952 \\
\hline Grasslands/Herbaceous & LC71 & G5 & $1,234,287$ \\
\hline Pasture/Hay & LC81 & G5 & 713,051 \\
\hline Row Crops & LC82 & G4 & 986,827 \\
\hline Small Grains & LC83 & G4 & 265,691 \\
\hline Fallow & LC84 & G4 & 71,346 \\
\hline Urban/Recreational Grasses & LC85 & G1 & 17,448 \\
\hline Woody Wetlands & LC91 & G2 & 216,131 \\
\hline Emergent Herbaceous Wetlands & LC92 & G5 & 90,452 \\
\hline Total & & & $7,692,677$ \\
\hline
\end{tabular}

a. Excludes water area as coded on either STATSGO or the Federal lands coverage.

A version of the NLCD was used in which the data with 30-meter resolution had been grouped into a set of 21 grids with $1-\mathrm{km}$ resolution, with each grid representing the proportion of one of the land cover classes (Limin Yang, personal communication, EROS Data Center, Sioux Falls, S. Dak., 2001). Table 1 shows the original classes and codes, and the area of each class is 
given, excluding the area of the water cells in the 1-km resolution dataset. The data from each of the 21 grids were attached to the combined grid of STATSGO and Federal land information using the ZONALSTATS algorithm in the GRID module of the Arc/Info geographic information system software. The proportions of the land cover cells were computed for each of the 129,520 unique combinations of STATSGO map unit, Federal Lands code, county, hydrologic cataloging unit, and Major Land Resource Area covering the conterminous United States.

The 21 classes were grouped into 5 generalized land cover classes (see tables 1 and 2). The

Table 2. Generalized land cover groups (aggregated from codes in table 1)

\begin{tabular}{|c|l|c|r|}
\hline $\begin{array}{c}\text { Generalized } \\
\text { code }\end{array}$ & \multicolumn{1}{|c|}{ Name for generalized class } & $\begin{array}{c}\text { Original class } \\
\text { codes }\end{array}$ & $\begin{array}{c}\text { Area in the } \\
\text { conterminous } \\
\text { United States }\left(\mathrm{km}^{2}\right)\end{array}$ \\
\hline \hline G1 & Water, Barren, Urban & $\begin{array}{c}\text { LC11, 12, 21, 22, 23, } \\
31,32,85\end{array}$ & 378,724 \\
\hline G2 & Forest, Transitional, Woody Wetlands & LC33, 41, 42, 43, 91 & $2,524,498$ \\
\hline G3 & Shrubland & LC51 & $1,410,840$ \\
\hline G4 & Cropland, Fallow, Orchards & LC61, 82, 83, 84 & $1,340,816$ \\
\hline G5 & Grasslands, Pasture, & LC71, 81, 92 & $2,037,790$ \\
\hline \hline & Herbaceous Wetlands & & $7,692,667$ \\
\hline
\end{tabular}

a. Excludes water area as coded on either STATSGO or the Federal lands coverage.

transitional class was grouped with forests, because in many cases the transition was a clearcut that is likely to regrow as forest.

In the detailed classifications of table 1, the Shrubland (LC51) and Grassland/Herbaceous (LC71) categories are dominant in area. When the classifications are aggregated as in table 2, the Forest (G2) category is dominant in area, followed by the Grassland (G5), Shrubland (G3), and Cropland (G4) categories.

\subsection{Maps of SOC on DOI land by generalized land cover class}

The assumption was made that the carbon content of each land cover type within the $1-\mathrm{km}^{2}$ cell was uniform, and the areas and carbon quantities for those cells were allocated to the land cover types. Statistics were computed for each of the original land cover classes and generalized land cover groups.

It is not convenient to try to map soil carbon according to the full detail of the distributions of land cover types within each $1 \mathrm{~km}^{2}$ grid cell. Therefore, the dominant land cover type was computed and used to stratify the DOI lands. A set of five maps was made, one for each of the dominant generalized land cover groups. An additional map shows the percentage of the $1 \mathrm{~km}^{2}$ 
grid cell represented by the dominant land cover type.

\subsection{A spatial hierarchy for analysis}

A hierarchy of spatial analysis areas provides summaries for all DOI lands, as well as the context in terms of national totals and details by Bureau. The hierarchy is outlined in table 3 , including the percentage of the land areas that are in Alaska. Indian trust lands are labeled as BIA (Bureau of Indian Affairs).

Table 3. Spatial analysis categories, total area, area in Alaska, and percentage in Alaska

\begin{tabular}{|c|c||l||r|r|r|}
\hline $\begin{array}{c}\text { Level of } \\
\text { hierarchy }\end{array}$ & $\begin{array}{c}\text { Spatial } \\
\text { Analysis } \\
\text { Code }\end{array}$ & \multicolumn{1}{|c||}{ Spatial Analysis Class } & $\begin{array}{c}\text { Total area } \\
\left(1,000 \mathrm{~km}^{2}\right)\end{array}$ & $\begin{array}{c}\text { Area in } \\
\text { Alaska } \\
\left(1,000 \mathrm{~km}^{2}\right)\end{array}$ & $\begin{array}{c}\text { Percentage } \\
\text { of land area } \\
\text { in Alaska (\%) }\end{array}$ \\
\hline \hline 1 & ALL & All land & 9,198 & 1,505 & 16.4 \\
\hline 2 & ANF & All non-Federal & 6,101 & 470 & 7.7 \\
\hline 2 & FED & Federal & 3,096 & 1,035 & 33.4 \\
\hline 3 & FNI & Federal, not Interior & 1,046 & 99 & 9.4 \\
\hline 3 & DOI & Dept. of Interior & 2,051 & 936 & 45.6 \\
\hline 4 & BLM & Bureau of Land Management & 1,058 & 351 & 33.2 \\
\hline 4 & FWS & Fish and Wildlife Service & 412 & 365 & 88.5 \\
\hline 4 & NPS & National Park Service & 321 & 220 & 68.6 \\
\hline 4 & BIA & Bureau of Indian Affairs & 252 & a & 0.1 \\
\hline 4 & BOR & Bureau of Reclamation & 7 & 0 & 0.0 \\
\hline
\end{tabular}

a. $328 \mathrm{~km}^{2}$.

The land areas of these categories sum according to the following equations:

$$
\begin{aligned}
& \mathrm{ALL}=\mathrm{ANF}+\mathrm{FED} \\
& \mathrm{FED}=\mathrm{FNI}+\mathrm{DOI} \\
& \mathrm{DOI}=\mathrm{BLM}+\mathrm{FWS}+\mathrm{NPS}+\mathrm{BIA}+\mathrm{BOR}
\end{aligned}
$$

\section{Results and Discussion}

\subsection{Summary}

Table 4 summarizes the carbon on DOI lands. The table shows that the 17.76 petagrams $(\mathrm{Pg} ; 1$ $\mathrm{Pg}=10^{15} \mathrm{~g}=1$ billion metric tons = 1 gigaton) of carbon on DOI lands represent 21.91 percent of the Nation's SOC. Over half of the carbon on DOI land is on lands managed by the BLM. It is important to note that nearly 74 percent of the DOI SOC is in Alaska. Similar information is shown for each DOI land management Bureau. More than 80 percent of the carbon on BLM and FWS lands is in Alaska, along with more than two-thirds of the carbon on NPS lands. 
Table 4. Soil organic carbon on Department of the Interior lands, by Bureau, with percentages of the national and department totals, and the percentage in Alaska [BLM = Bureau of Land Management; FWS = Fish and Wildlife Service; NPS = National Park Service; BIA = Indian trust lands associated with the Bureau of Indian Affairs; BOR = Bureau of Reclamation]

\begin{tabular}{|l|r|r|r|r|r|r|}
\hline & \multicolumn{1}{|c|}{$\begin{array}{c}\text { Carbon } \\
(\mathrm{Pg})\end{array}$} & $\begin{array}{c}\text { Area } \\
\left(\mathrm{km}^{2}\right)\end{array}$ & $\begin{array}{c}\text { Carbon } \\
\left(\mathrm{kg} \mathrm{m}^{-2}\right)\end{array}$ & $\begin{array}{c}\text { Carbon as a } \\
\text { percentage } \\
\text { of the } \\
\text { national } \\
\text { total } \\
(\%)\end{array}$ & $\begin{array}{c}\text { Carbon as a } \\
\text { percentage } \\
\text { of the DOI } \\
\text { lands total } \\
(\%)\end{array}$ & $\begin{array}{c}\text { Percentage } \\
\text { of carbon } \\
\text { that is in } \\
\text { Alaska } \\
(\%)\end{array}$ \\
\hline \hline BLM & 9.40 & $1,057,772$ & 8.89 & 11.59 & 52.93 & 80.43 \\
\hline FWS & 5.43 & 412,176 & 13.18 & 6.70 & 30.57 & 82.50 \\
\hline NPS & 1.49 & 321,373 & 4.64 & 1.84 & 8.39 & 68.46 \\
\hline BIA & 1.41 & 252,348 & 5.59 & 1.74 & 7.94 & 0.14 \\
\hline BOR & 0.02 & 6,755 & 3.43 & 0.02 & 0.11 & 0.00 \\
\hline \hline DOI Total & 17.76 & $2,050,514$ & 8.66 & 21.91 & 100.00 & 73.59 \\
\hline
\end{tabular}

\subsection{SOC by soil depth and land cover for the conterminous United States}

Tables 5 to 8 use the spatial analysis categories of table 3 with the generalized land cover categories of table 2 to summarize information for the conterminous United States. Equivalent land cover information was not available for Alaska. Table 5 gives the land area for these analysis units. Although the area of Forests (G2) is dominant when considering all ownerships, on Federal lands the Shrublands (G3) are dominant, followed by Forests (G2) and Grasslands (G5). The DOI lands represent 54 percent of Federal lands, but with large areas of forest under the management of the Department of Agriculture's Forest Service, the ranking for DOI lands is Shrubland (G3) > Grassland (G5) > Forest (G2).

Tables 7 and 8 give the SOC for the depth zones 0 to $100 \mathrm{~cm}$ and 0 to $30 \mathrm{~cm}$, respectively. Of the 61.6 Pg of SOC in the total profile in the conterminous United States, 51.0 Pg (approximately 83 percent) are in the top meter of soil, and $29.0 \mathrm{Pg}$ (approximately 47 percent) are in the top 30 $\mathrm{cm}$ of soil. This reflects the processes of organic matter incorporation into the soil, which are often dominated by the surface incorporation of leaf litter and organic matter derived from the mortality of shallow roots.

Table 6 gives the SOC in the total soil profile (to the depth of measurement or data reporting) by land cover group. Even though the conterminous United States represents only 26 percent of the DOI lands' SOC, it is useful to note its distribution by land cover groups. The magnitudes of SOC are nearly equal in the dominant categories, with Shrubland (G3) > Forest (G2) > Grassland (G5). Most of the Shrubland SOC is on lands under BLM management, most of the Forest SOC is 

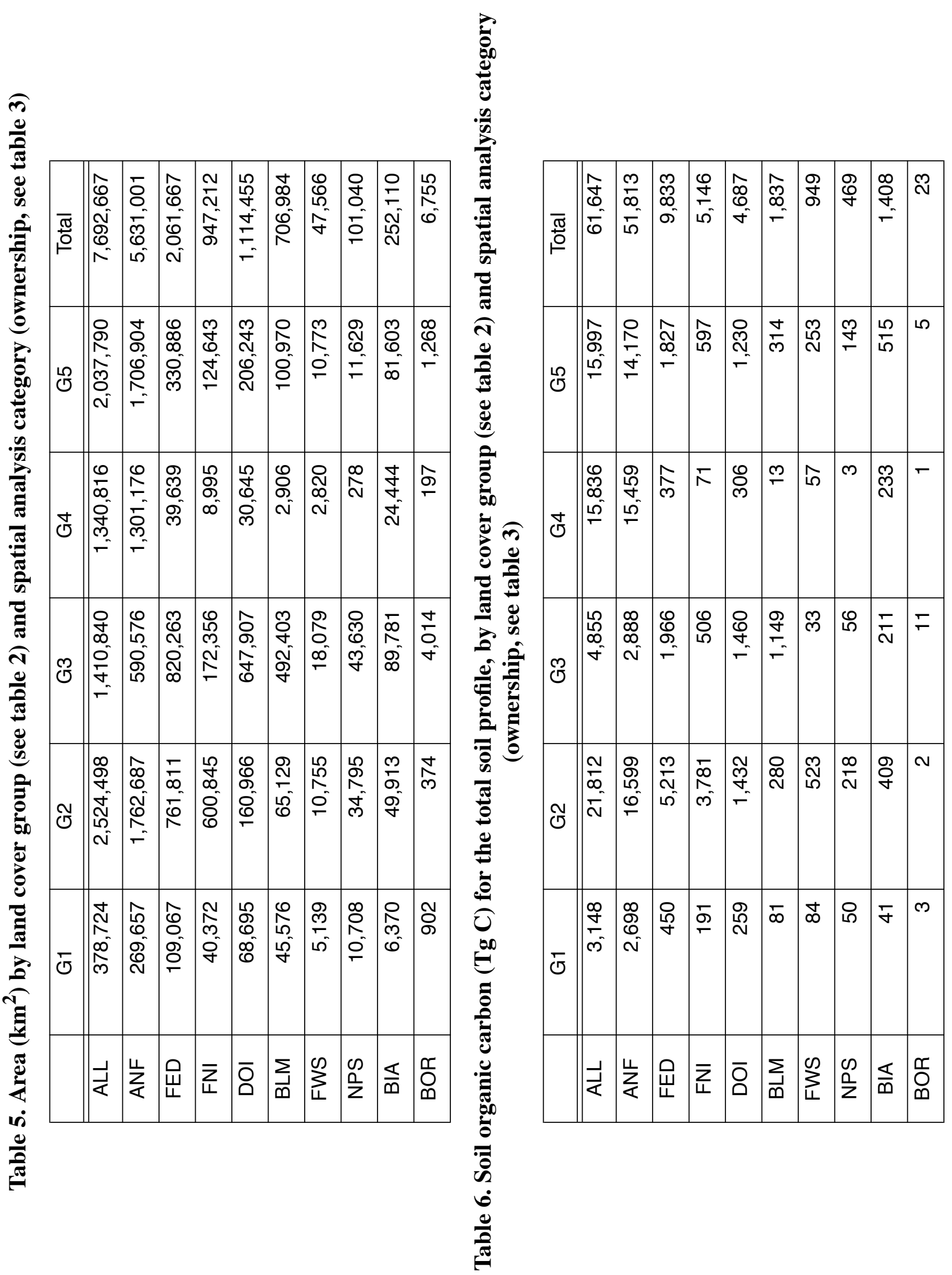


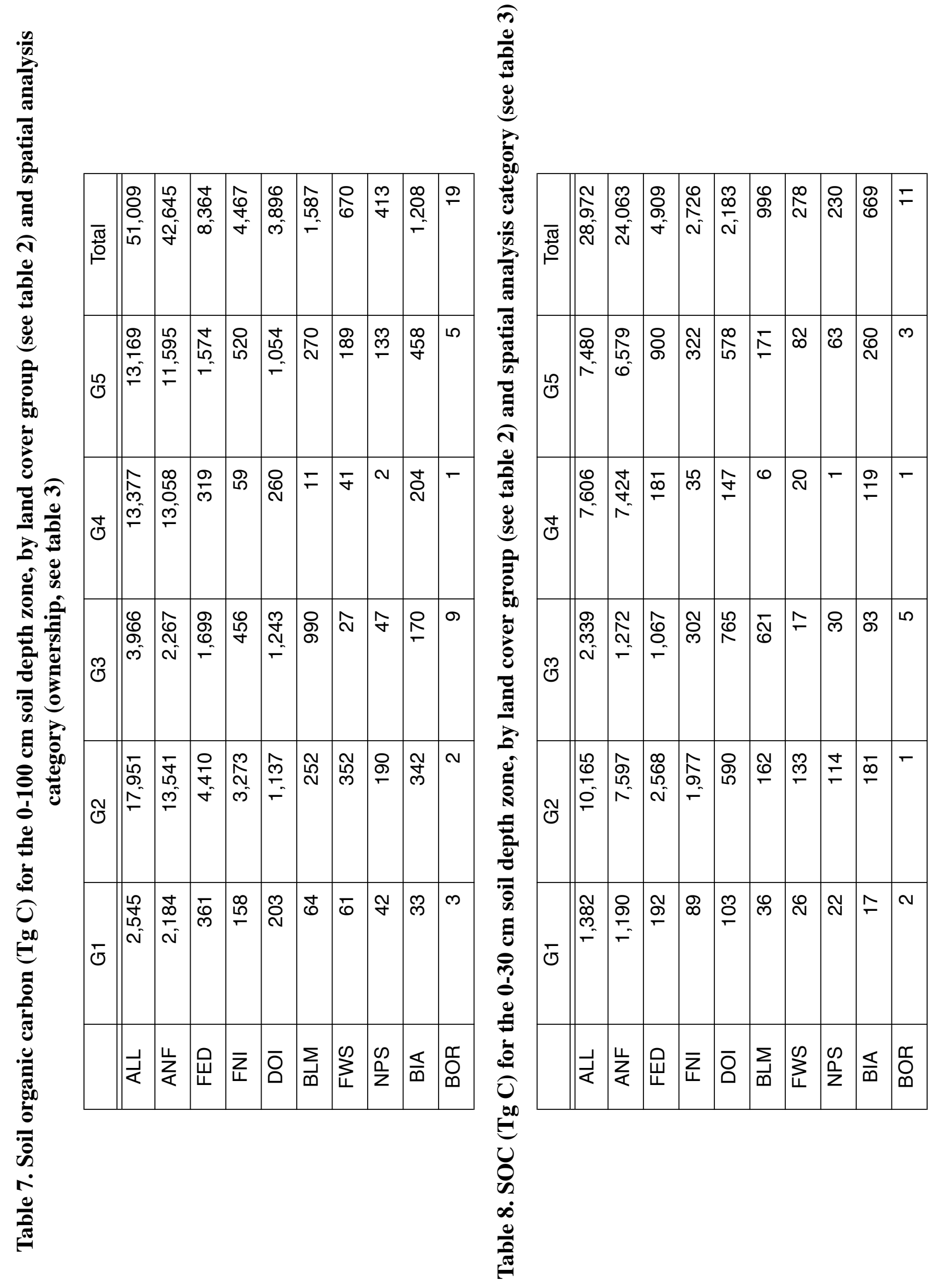


on lands under FWS and BIA management, and most of the Grassland SOC is on lands under BIA and BLM management.

In a similar way, tables 9 to 12 use the spatial analysis categories of table 3 with the detailed land cover categories of table 1 . Table 9 gives the land area for these analysis units. Table 10 gives the SOC in the total soil profile. Tables 11 and 12 give the SOC for the depth zones 0 to $100 \mathrm{~cm}$ and 0 to $30 \mathrm{~cm}$, respectively. The Shrubland (LC51) category on BLM lands has the dominant values in these categories for DOI lands.

In all of these tables, the entries become less reliable when the areas involved are small.

\subsection{Maps}

Appendix B contains three sets of maps to illustrate the SOC on DOI lands. The first set illustrates Federal land areas. The second set shows SOC both for the conterminous United States and for Alaska, in the context of the spatial hierarchy. The third set focuses just on the DOI lands in the conterminous United States but separates them by the dominant land cover groups.

\subsubsection{The extent of Federal and DOI lands}

Figure B1 shows the extent of Federal lands and illustrates the split of the All non-Federal category and the Federal category as given in table 3 for "Level of hierarchy $=2$." The partitioning of the DOI lands by Bureau is shown in figure B2, corresponding to "Level of hierarchy = 4" in table 3 .

\subsubsection{DOI carbon in a spatial context}

A series of 12 maps for the conterminous United States and Alaska is given in figures B3 to B14, with one map for each of the categories in the spatial hierarchy introduced in table 3 . Two of the maps in the series are designed for special purposes, to show the influences of changing the map legend (figure B4) and soil depth (figure B9). Except for these cases, the map legends are consistent with a maximum threshold of $20 \mathrm{~g} \mathrm{C} \mathrm{m}^{-2}$ and show the SOC for the total recorded soil profile.

Figure B3 has the most comprehensive map of the series, showing SOC on all lands for the total soil profile. High levels of SOC often reflect wet and cold soils, such as in the Des Moines lobe of the continental glaciation in Minnesota and Iowa, the temperate rainforest of the coastal areas of Oregon and Washington, the coastal areas of Alaska, or the wetlands along the Atlantic and Gulf coasts. The high SOC levels in parts of Texas may be due more to physical protection in the soil structure than to wet or cold conditions.

Map B4 shows the same data as map B3, the SOC for DOI lands in the conterminous United States and Alaska. It uses $80 \mathrm{~kg} \mathrm{~m}^{-2}$ rather than $20 \mathrm{~kg} \mathrm{~m}^{-2}$ for the maximum category in the map legend, showing greater detail in areas with high concentrations of SOC, such as in Alaska, Minnesota, Wisconsin, and Michigan. The $0-20 \mathrm{~kg} \mathrm{~m}^{-2}$ range was used for the legend in the rest of 


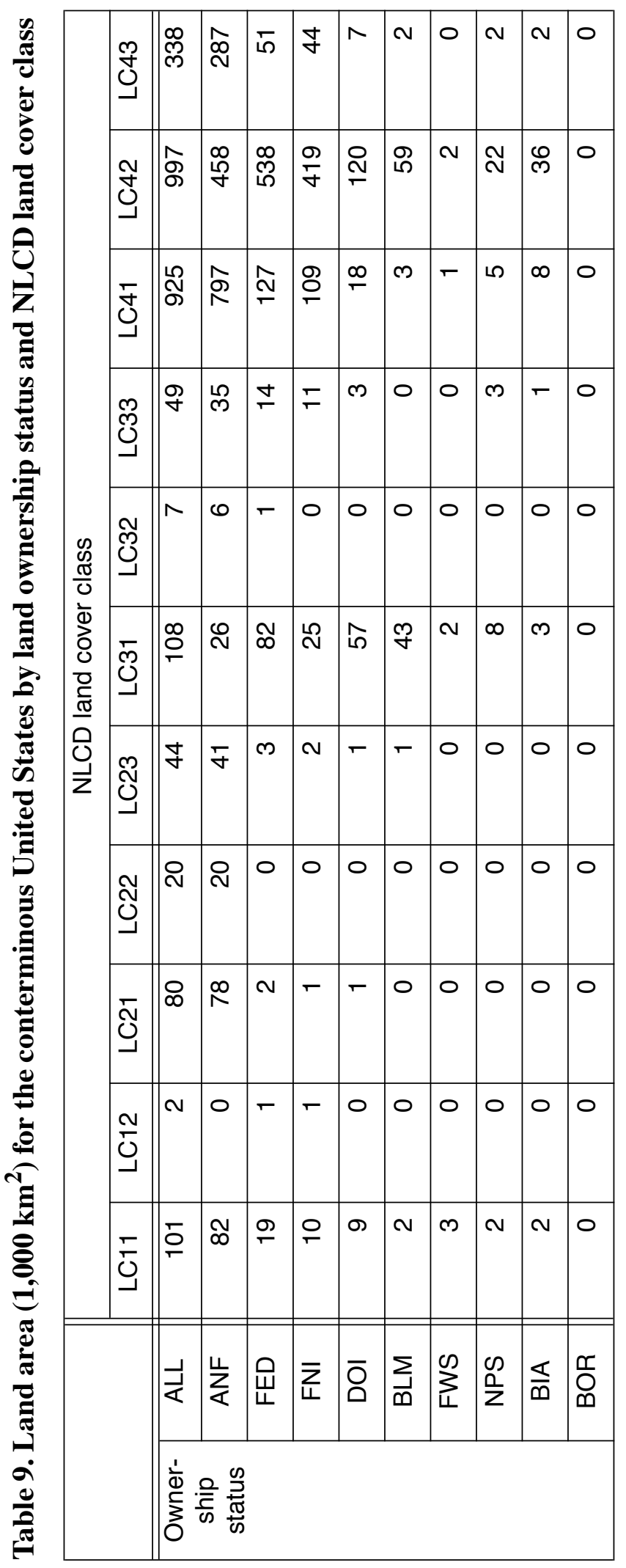

\begin{tabular}{|c|c|c|c|c|c|c|c|c|c|c|}
\hline $\begin{array}{l}\bar{\pi} \\
\stackrel{0}{0}\end{array}$ & $\mid \begin{array}{l}0 \\
0 \\
0 \\
\end{array}$ & 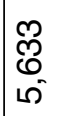 & $\begin{array}{l}\text { N } \\
\text { O } \\
\text { Ni }\end{array}$ & 守 & $\frac{⿱}{\stackrel{\Xi}{\tau}}$ & $\hat{R}$ & $\stackrel{\infty}{+}$ & 으 & N & $\Lambda$ \\
\hline త్రి & ৪ & $\stackrel{\bullet}{N}$ & $\stackrel{ \pm}{ \pm}$ & $m$ & $\mp$ & $r$ & 10 & ल & $\sim$ & 0 \\
\hline ర్త & $\frac{0}{N}$ & $\stackrel{\stackrel{\infty}{\infty}}{-}$ & $\bar{m}$ & $\stackrel{\infty}{-}$ & $\stackrel{m}{\sim}$ & 0 & 0 & $\infty$ & $\infty$ & 0 \\
\hline 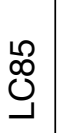 & $\approx$ & 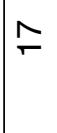 & $r$ & $r$ & 0 & 0 & 0 & 0 & 0 & 0 \\
\hline $\begin{array}{l}\text { Ð } \\
\text { త్ }\end{array}$ & $\pi$ & ஜ్రి & $\infty$ & $\tau$ & $\wedge$ & $\tau$ & 0 & 0 & 0 & 0 \\
\hline $\begin{array}{l}\mathscr{2} \\
\text { Oુ } \\
\end{array}$ & 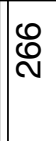 & $\stackrel{i}{\stackrel{n}{N}}$ & $\stackrel{\sim}{\longrightarrow}$ & $\sim$ & $\stackrel{m}{\sim}$ & $\tau$ & - & 0 & $\mp$ & 0 \\
\hline జ్త & 吕 & న్ & $\mathscr{0}$ & 0 & 으 & - & $\sim$ & 0 & $\Lambda$ & 10 \\
\hline $\begin{array}{l}-\infty \\
0 \\
0\end{array}$ & $\frac{m}{1}$ & \begin{tabular}{l}
0 \\
$\infty$ \\
\hdashline
\end{tabular} & $\hat{N}$ & $\stackrel{m}{-}$ & $\stackrel{ \pm}{ \pm}$ & $\nabla$ & $r$ & 0 & $\infty$ & 0 \\
\hline $\begin{array}{c}\bar{U} \\
\mathcal{U}\end{array}$ & Wָ & ষ্ঠ & న্ & $\stackrel{\infty}{\circ}$ & $\underset{\infty}{\infty}$ & পே & 10 & $\infty$ & $\stackrel{N}{N}$ & $r$ \\
\hline త্త & $\underline{\sim}$ & 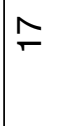 & 0 & 0 & 0 & 0 & 0 & 0 & 0 & 0 \\
\hline కొ & $\frac{\sigma_{0}}{\sigma_{n}}$ & চ్ & 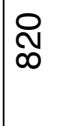 & $\stackrel{N}{N}$ & 我 & ๙ু & $\stackrel{\infty}{-}$ & \& & ৪ & $\nabla$ \\
\hline & 光 & 岁 & 邑 & $\sum_{\longleftrightarrow}$ & $\overline{\mathrm{D}}$ & $\sum_{\vec{\omega}}$ & $\sum_{4}^{\infty}$ & 足 & $\frac{\overleftarrow{\omega}}{\infty}$ & $\begin{array}{l}\text { qu } \\
\text { ○् }\end{array}$ \\
\hline
\end{tabular}




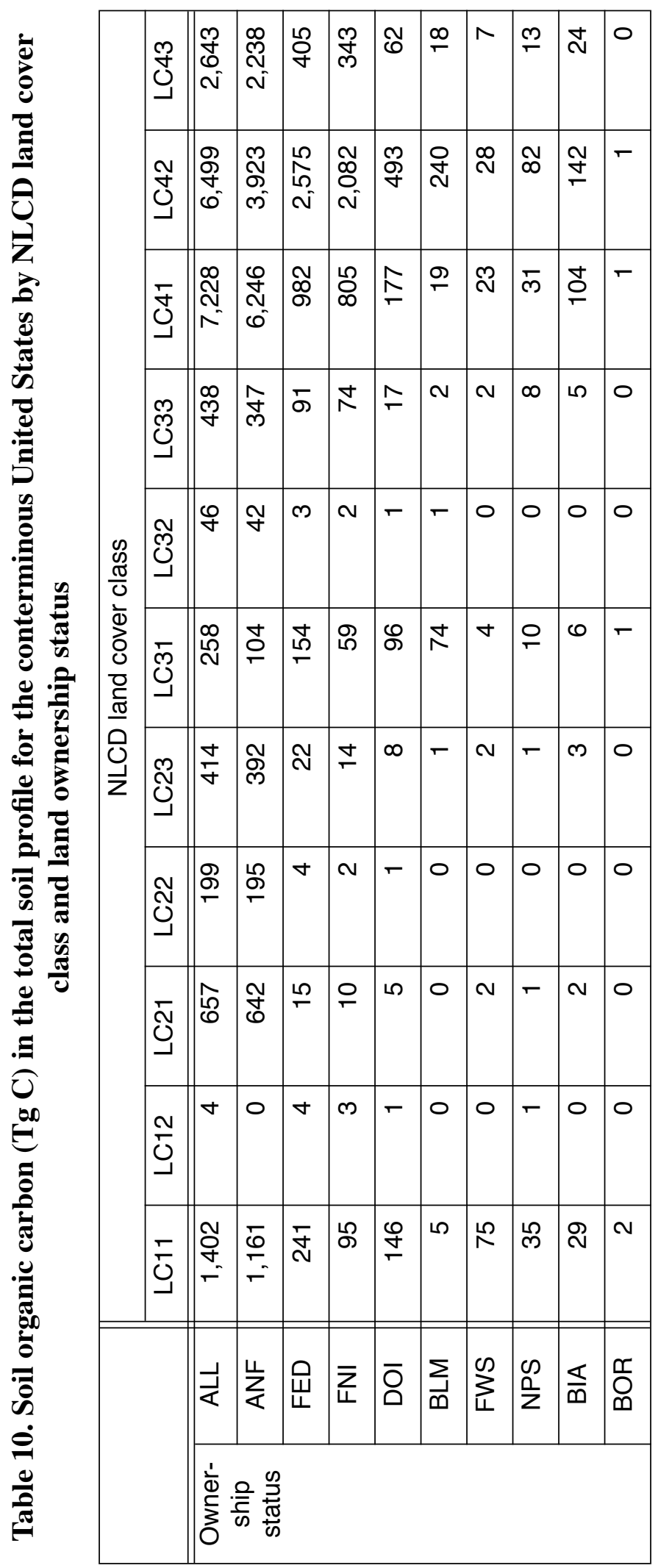

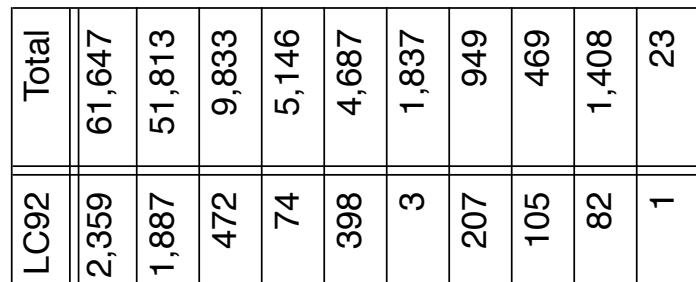

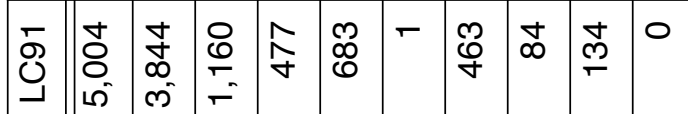

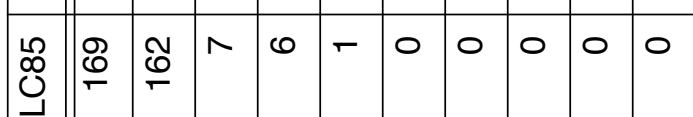

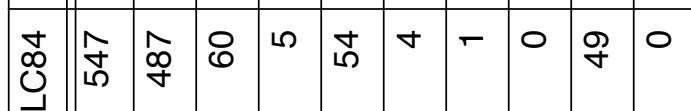

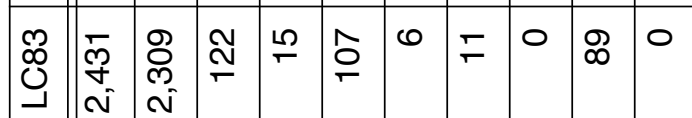

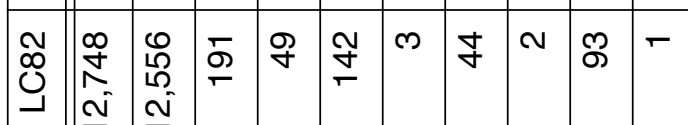

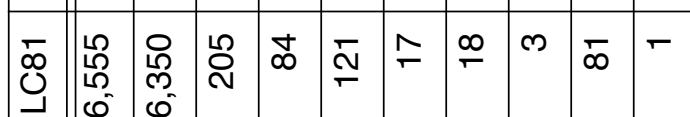

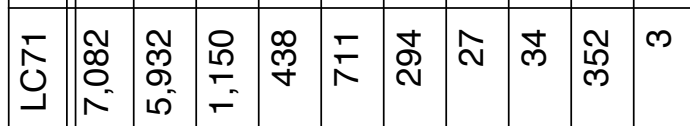
ธ்َ

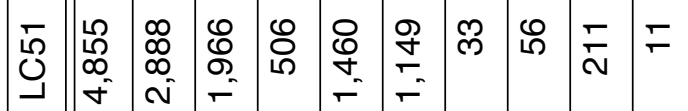
马岀崫位 


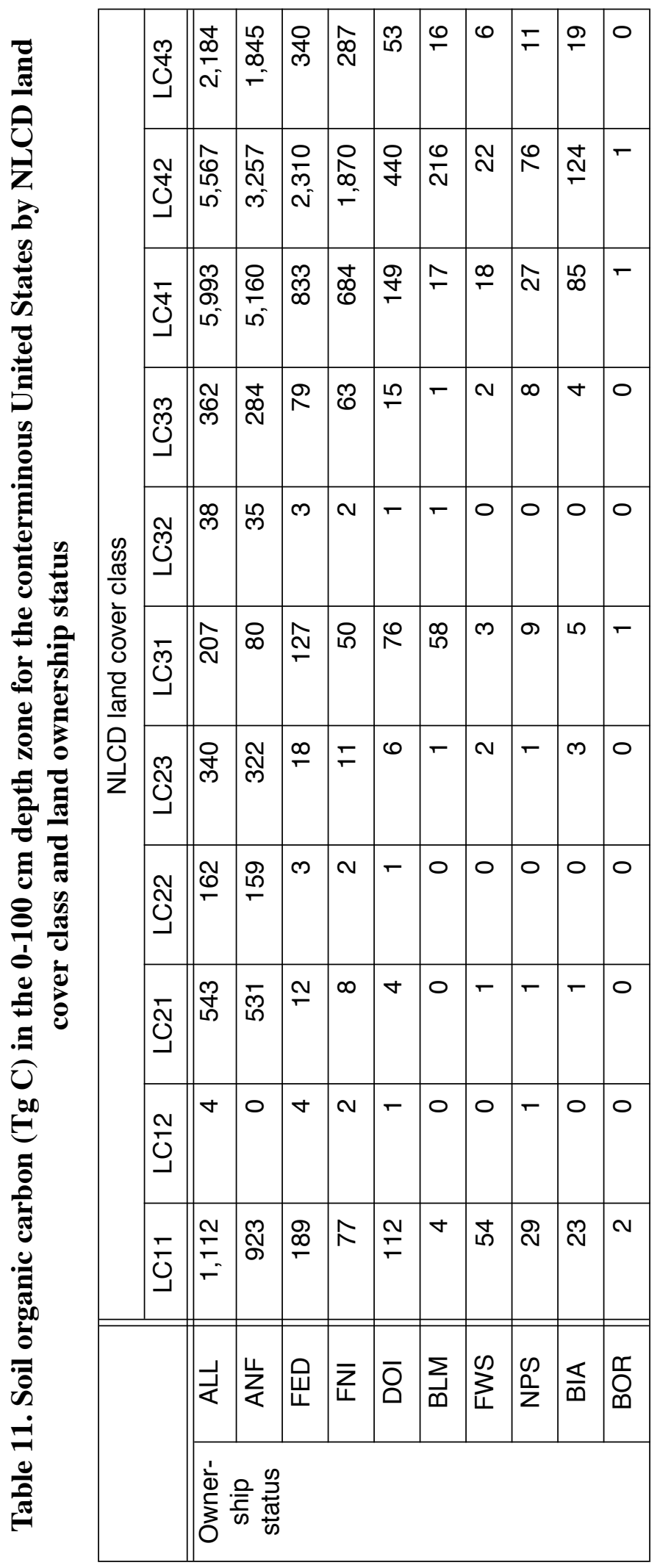

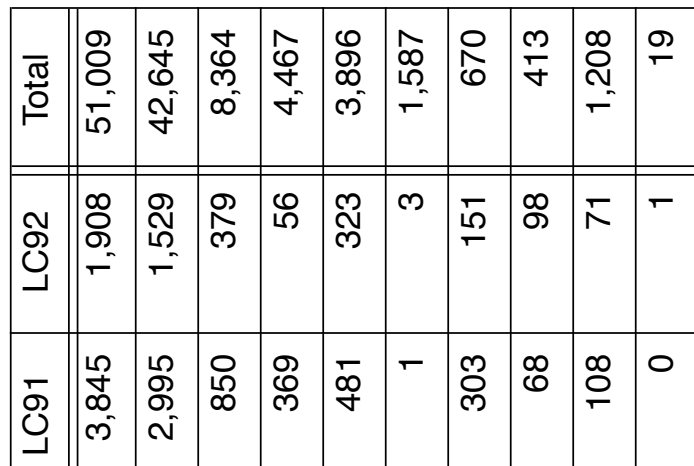

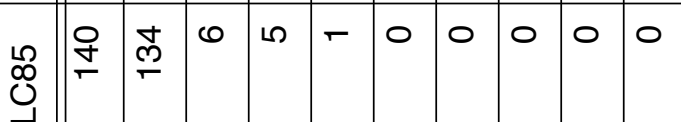

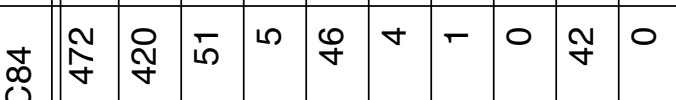

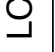

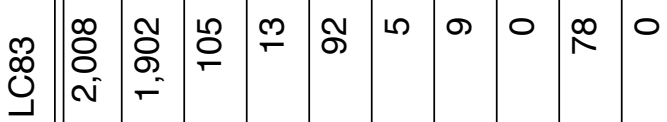
N U.

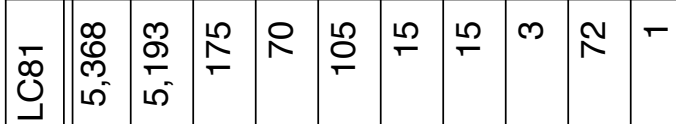

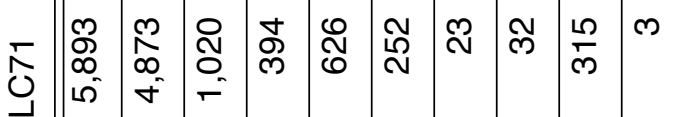

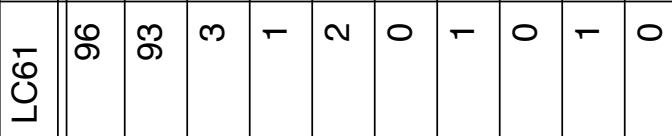

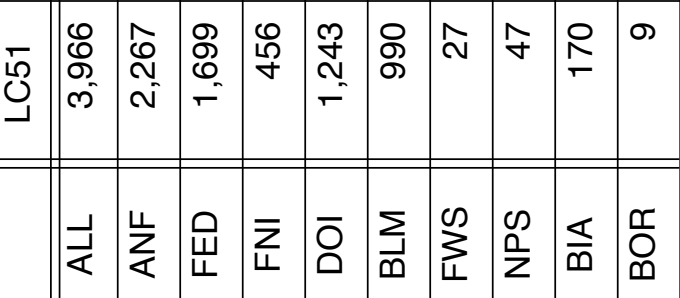




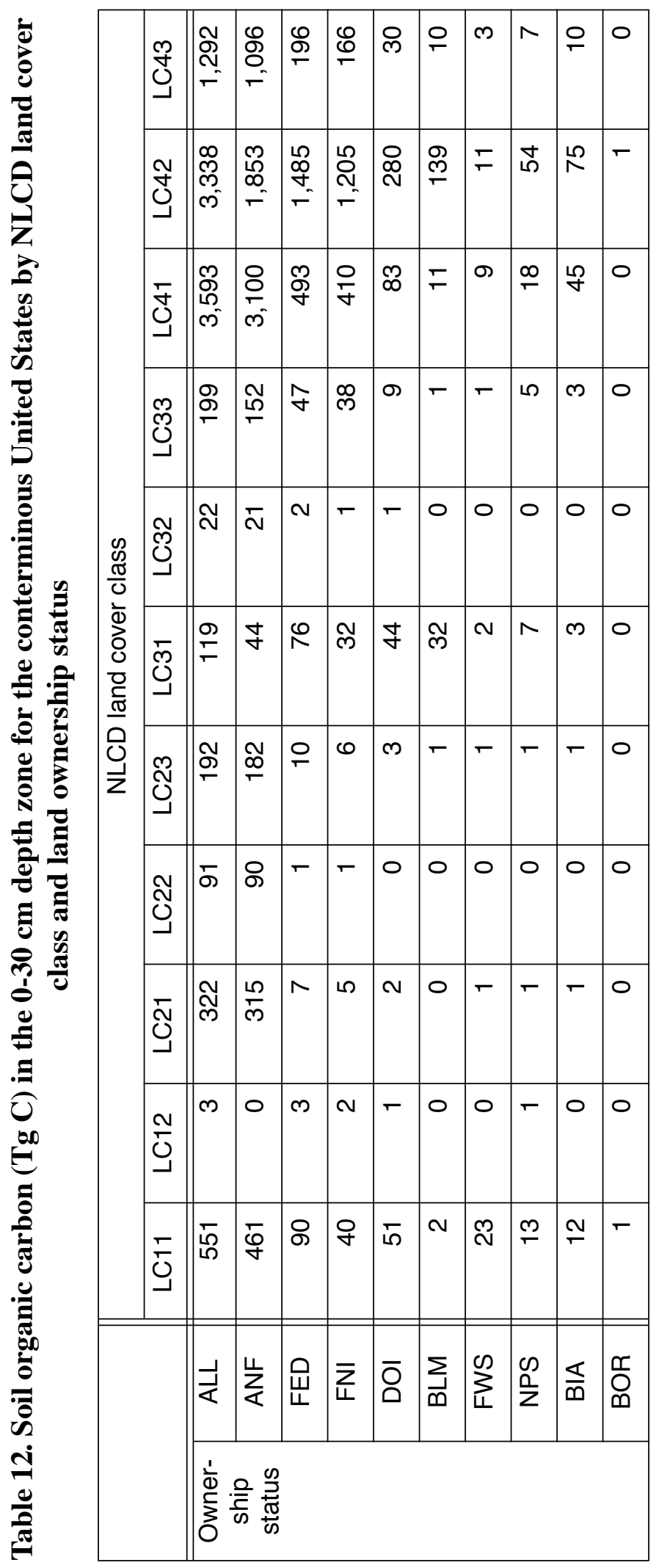

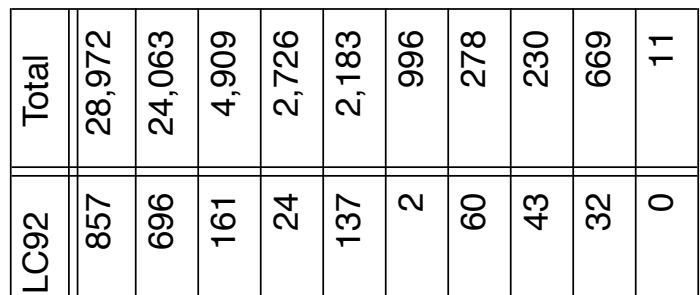

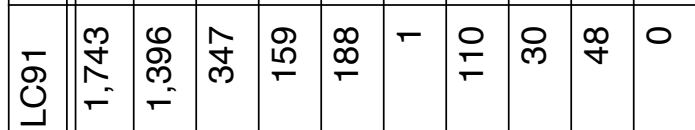

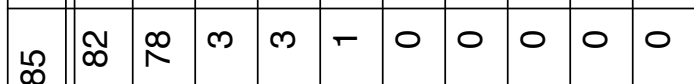
禹

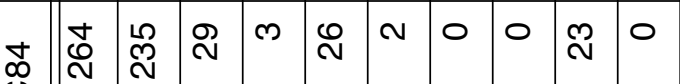
U్త

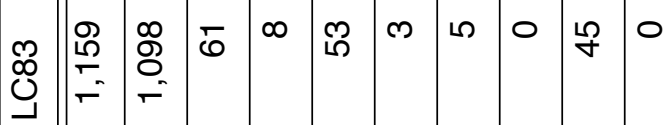

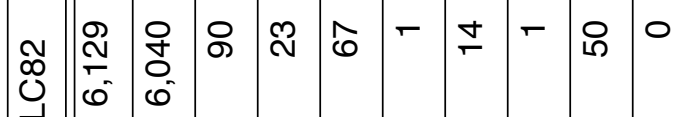

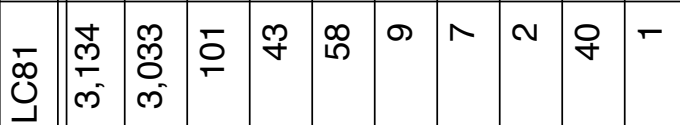

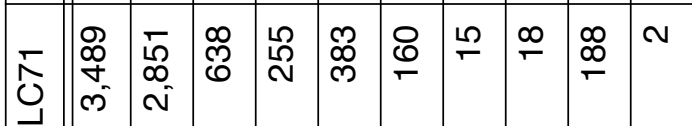

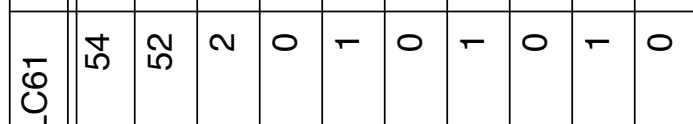
ᄃ্ூ 
the series so that the patterns of SOC in other areas of the United States would be visible on the map, particularly the variations in the Western States that are visible in map B3 but not in B4.

The maps in figures B5 and B6 complement each other, showing the non-Federal and Federal lands, respectively. In general, the more biologically productive lands are non-Federal, and the average non-Federal carbon content $\left(9.47 \mathrm{~kg} \mathrm{C} \mathrm{m}^{-2}\right)$ is only 25 percent higher than the average for the Federal lands $\left(7.53 \mathrm{~kg} \mathrm{C} \mathrm{m}^{-2}\right)$ because of the extremely high carbon concentrations on Federal lands in Alaska.

Figures B7 and B8 partition the Federal lands into the non-DOI agencies and the DOI lands, respectively. Most of the large landholdings reflected in the non-DOI map are under the jurisdiction of the U.S. Department of Agriculture (USDA) Forest Service (http://www.fs.fed.us/). The partitioning of the SOC on DOI lands between Alaska and the conterminous United States was given above in table 4 .

Figure B9 shows SOC for the conterminous United States and Alaska for DOI lands in the 0$30 \mathrm{~cm}$ soil depth. The same spatial extent is shown as in map B8, but it highlights the more active surface zone. Except in Alaska, much of the SOC below this layer is considered "passive" and may have turnover times measured in the hundreds to thousands of years. The conditions in Alaska may be different owing to the presence of permafrost and to cryoturbation--a mixing of the soil during the freeze-thaw cycle. Details of the depth distribution of SOC are given in the tables cited in section 3.2 above.

Figures B10 through B14 show SOC for each of the DOI land management Bureaus, in order of decreasing land area. Although the BLM (figure B10) has the largest amount of SOC (9.40 Pg), the SOC per unit area is highest for the FWS (figure B11) owing to significant areas of wetlands. The SOC in Alaska dominates the distributions for both Bureaus. The NPS (figure B12) has diverse holdings, from rocky mountain tops to wet coastal areas. Almost all the land associated with the BIA (figure B13) is in the conterminous United States and has a variety of land types, including grasslands and shrublands. The area of BOR land (figure B14) is comparatively small (less than 1 percent of the BLM total) and has lower SOC than the land of the other Bureaus, reflecting the drier landscapes associated with western water projects.

\subsubsection{Carbon on DOI lands by generalized land cover group}

Figures B15 to B19 are a set of five maps focusing on the DOI lands, with each map representing one of the generalized land cover groups introduced in table 2. The DOI shrublands (map B17) have approximately the same quantity of carbon (1.66 Pg C) as the DOI Forest, Transitional, and Woody Wetlands (map B16; $1.50 \mathrm{Pg} \mathrm{C}$ ), but the shrubland area is much larger, and the carbon intensities are only 23 percent as high, on average. Most of the cropland areas (figure B18) are on lands associated with the BIA. Most of the grassland areas (figure B19) are on lands associated with the BIA or the BLM (see also table 6). 


\subsubsection{Influence of using dominant generalized land cover group on the maps}

In addition to the attribute generalization, there is some spatial generalization represented in this set of maps. The summary of the land areas and SOC contents presented in tables 5 to 8 was computed using the full detail of the proportional area of the land cover data (originally classified from imagery with 30-meter pixels). Although this detail is useful, it is not readily visualized. To create understandable maps, it is necessary to simplify the data by evaluating the dominant land cover group within each $1 \mathrm{~km} \mathrm{x} 1 \mathrm{~km}$ grid cell. The dominant generalized land cover group for each grid cell (see tables 2 and 3) was used to select the grid cells within the DOI lands to be displayed on each map. The average soil carbon for the $1 \mathrm{~km}^{2}$ grid cell is used to color the map.

The analysis for maps B15 to B19 does not account for differences in the carbon content by land cover type within a $1 \mathrm{~km}^{2}$ grid cell. To do so would require information from other data sources, which was not part of the scope of this investigation.

A discussion of the differences in the statistics computed using the detailed and the dominant approaches is given in appendix $\mathrm{C}$.

\subsection{Importance of SOC on DOI lands}

The DOI has jurisdiction influencing approximately 22 percent of the Nation's land area. Additional research is needed on how land management decisions on fire suppression, clearing fire fuels, draining or restoring wetlands, and grazing intensities will affect carbon stocks on DOI lands. The land managers need to know the impacts that nonmanaged processes, such as climate feedbacks, will have on the carbon stocks of the lands they manage.

The maps presented in this paper are an estimate of the current stocks of SOC on DOI lands, placed in the context of SOC on all lands and Federal lands. The DOI lands have about 22 percent of the Nation's SOC, so the average carbon intensity (8.66 kilograms per square meter) approximates the average for all lands $\left(8.81 \mathrm{~kg} \mathrm{~m}^{-2}\right)$. However, the carbon on DOI lands is not evenly distributed. Of the $17.76 \mathrm{Pg}$ of SOC on DOI lands, $13.07 \mathrm{Pg}$ (74 percent) are in Alaska and 4.69 Pg (26 percent) are in the conterminous United States. The Alaska soils are wetter and colder than the national average, and the DOI lands in the conterminous United States are warmer and dryer than the average.

\subsection{Strengths and limitations of the STATSGO data source}

The STATSGO data represent the first comprehensive digital data base of soil geographic information for the United States. The Soil Conservation Service (now the NRCS) developed the database in the mid-1980s, using general soil maps compiled as part of the National Cooperative Soil Survey. The map units were delineated on 1:250,000-scale U.S. Geological Survey quadrangle maps before being digitized. The attribute data were extracted from a database known as the Soil Interpretations Record. The data are suitable for statewide, regional, and national analysis. The expert judgement of many qualified soil scientists is represented in these databases.

The STATSGO data have some limitations for the purposes of this paper. The most important 
limitation is that the linkage to measured soil samples was not maintained when the database was created. Consequently, it is not possible to treat the STATSGO data as a point in a time series, to evaluate changes over time. The current STATSGO data structure does not provide for incorporating data from new soil sampling into the framework. A prototype method for doing this has been devised for the North Slope of Alaska (Bliss, Ping, Waltman, and Michaelson, unpub. data, 2003).

In some cases, there are deficiencies in the attribute data. Some LAYER records have organic matter (carbon) values but are missing a bulk density value. No effort was made to fill in missing values, except that an estimated bulk density value of 0.40 was used for organic soils if the data record showed zero values (Sharon Waltman, NRCS, personal communication). The organic matter values in the LAYER table appear to have been rounded to the nearest half percent $(0.5$ percent), so in cases of very low organic matter contents, a zero was reported in the database. It is not possible to tell if the zero is an appropriate value or is the result of rounding values of less than 0.5 percent.

One aspect of the general nature of the STATSGO data is not an issue in this paper. The generalized nature of the spatial and attribute data means that the carbon content at any particular point is only known in terms of a distribution of possible values. Although this would be a problem for relating STATSGO to site-specific data sources, that was not necessary for this study, and the capability to aggregate the statistical distributions within larger spatial units has worked well to give reasonable estimates of the SOC contents and stocks for large areas.

\subsection{Strengths and limitations of the Federal lands data source}

The Federal lands dataset is part of a 1:2,000,000-scale series of maps distributed by the USGS. It is suitable for the type of overview analysis presented in this paper.

The data for the Federal lands coverage did not include land areas of less than $1 \mathrm{~km}^{2}$. It is not known what influence this has on the statistics presented here. There are many inholdings and intermixtures of private and public lands in the Western United States. The maps shown here seem reasonable, even though more accurate spatial databases may be available in the future. It is unlikely that the conclusions on the carbon contents of DOI lands would be changed substantially if the analysis were to be repeated using a more detailed Federal lands coverage.

\subsection{Strengths and limitations of the land cover data source}

The NLCD represents the most detailed land cover classification that is available of the conterminous United States. The nominal date for the data used in this analysis was 1992, but the imagery may have been used from a year before or a year following the nominal date. The 30meter resolution of the data represents a finer detail than is needed for the purposes of this paper, but the statistical representation of that detail is valuable for obtaining unbiased estimates of the land cover proportions. The discussion in appendix $\mathrm{C}$ shows that some bias may be introduced if the dominant land cover type within a $1-\mathrm{km}^{2}$ cell is used instead of the detailed data. 
The Multiresolution Land Characterization project is developing a new land cover characterization dataset with a nominal image date of 2000. When this is available, it will allow an updated analysis by land cover category and will make possible additional investigations of the role of land cover change on DOI lands.

\section{Conclusions}

The estimates of SOC presented in this paper should be integrated with estimates of aboveground and belowground biomass to gain a better picture of the total carbon stocks on the landscape, for DOI lands and for the Nation as a whole. More linkages to soil pedon data will allow better estimates of SOC stocks and better simulation of the dynamic processes that lead to carbon sequestration or release.

The data presented here are essential to an accounting of carbon fluxes on DOI lands. It will be very important for answering a set of "what if" questions, using models to simulate scenarios of the impacts of potential changes in land cover or land management. Some possible changes would be the encroachment of shrub vegetation into grassland areas, changes in grazing intensities, changes in fire suppression practices, and changes in the management of wetlands.

The DOI has jurisdiction for many lands that are not intensively managed, yet which could respond to changes in their environment, such as climate change. This may be particularly important in Alaska, where DOI lands have large stocks of SOC, and there is a potential for significant impacts from global warming. These possibilities should be evaluated as part of a national accounting of carbon sequestration and release.

The datasets used in this study can also be used for other purposes, such as estimating rates of carbon erosion on the landscape. Erosion estimates can be coupled with data from digital elevation models to estimate rates at which carbon may be trapped in sediments in valleys and behind dams on DOI land.

The estimates of SOC stocks presented here can guide future research. Critical research questions deal with the dynamics of SOC and the effects of various current and potential management practices. With 22 percent of the Nation's soil carbon, the DOI lands are likely to be important in a national accounting of greenhouse gas emission and sequestration.

\section{Acknowledgments}

The author appreciates the support of the USGS Geographic Analysis and Monitoring Program. Bruce Wylie, Eric Sundquist, and Mike Budde reviewed a draft of the manuscript.

\section{References}

Bliss, N.B., Waltman, S.W., and Petersen, G.W., 1995, Preparing a soil carbon inventory for the United States using geographic information systems, in Lal, R., Kimble, J., Levine, E., and Stewart, B.A. (eds.), Soils and Global Change, Advances in Soil Science: Boca Raton, Fla., Lewis Publishers, CRC Press, p. 275-295.

Donigian, A.S., Jr., Patwardhan, A.S., Jackson, R.B., IV., Barnwell, T.O., Jr., Weinrich, K.B., and 
Rowell, A.L., 1995, Modeling impacts of agricultural management practices on soil carbon in the Central U.S., in Lal, R., Kimble, J., Levine, E., and Stewart, B.A. (eds.), Soil Management and Greenhouse Effect, Advances in Soil Science: Boca Raton, Fla., Lewis Publishers, CRC Press, p. 121-135.

Herrick, J.E. and Wander, M.M., 1998, Relationships between soil organic carbon and soil quality in cropped and rangeland soils: the importance of distribution, composition, and soil biological activity, in Lal, R., Kimble, J., Follett, R.F., and Stewart, B.A. (eds.), Soil Processes and the Carbon Cycle, Advances in Soil Science: Boca Raton, Fla., Lewis Publishers, CRC Press, p. 405-425.

Janzen, H.H., Campbell, C.A., Gregorich, E.G., and Ellert, B.H., 1998, Soil carbon dynamics in Canadian agroecosystems, in Lal, R., Kimble, J., Follett, R.F., and Stewart, B.A. (eds.), Soil Processes and the Carbon Cycle, Advances in Soil Science: Boca Raton, Fla., Lewis Publishers, CRC Press, p. 57-80.

Kolchugina, T.P., Vinson, T.S., Gaston, G.G., Rozhkov, V.A., and Shwidenko, A.Z., 1995, Carbon pools, fluxes, and sequestration potential in soils of the Former Soviet Union, in Lal, R., Kimble, J., Levine, E., and Stewart, B.A. (eds.), Soil Management and Greenhouse Effect, Advances in Soil Science: Boca Raton, Fla., Lewis Publishers, CRC Press, p. 25-40.

Lal, R., Kimble, J., and Stewart, B.A., 1995, World soils as a source or sink for radiatively-active gases, in Lal, R., Kimble, J., Levine, E., and Stewart, B.A. (eds.), Soil Management and Greenhouse Effect, Advances in Soil Science: Boca Raton, Fla., Lewis Publishers, CRC Press, p. 1-7.

Lal, R. and Kimble, J.M., 2000, Soil C pool and dynamics in cold ecoregions, in Lal, R., Kimble, J.M., and Stewart, B.A. (eds.), Global Climate Change and Cold Region Ecosystems, Advances in Soil Science: Boca Raton, Fla., Lewis Publishers, CRC Press, p. 3-28.

Michaelson, G.J., Ping, C.L., and Kimble, J.M., 1996, Carbon storage and distribution in tundra soils of arctic Alaska, U.S.A: Arctic and Alpine Research, v. 28, no. 4, p. 414-424.

Mitsch, W.J. and Wu, X., 1995, Wetlands and global change, in Lal, R., Kimble, J., Levine, E., and Stewart, B.A. (eds.), Soil Management and Greenhouse Effect, Advances in Soil Science: Boca Raton, Fla., Lewis Publishers, CRC Press, p. 205-230.

NLCD, 2002, National Land Cover Data 1992 (NLCD 92): National Land Cover Characterization Project [http://landcover.usgs.gov/natllandcover.html] accessed August 8, 2002.

NRCS Soil Survey Staff, 1994, State soil geographic data base (STATSGO) data use information: Miscellaneous Publication 1492, Natural Resources Conservation Service, Ft. Worth, Texas, U.S. Department of Agriculture [http://www.ftw.nrcs.usda.gov/stat_data.html].

NRCS Soil Survey Staff, 1996, Soil Survey Laboratory Methods Manual, Soil Survey Investigations Report No. 42, Version 3.0, Lincoln, Neb., National Soil Survey Center [http:// soils.usda.gov/procedures/lmm/main.htm].

Oechel, W.C., Hastings, S.J., Vourlitis, G., Jenkins, M., Riechers, G., and Grulke, N., 1993, Recent change of Arctic tundra ecosystems from a net carbon dioxide sink to a source: Nature, v. 361, p. 520-523.

Oechel, W.C., Vourlitis, G.L., Hastings, S.J., Zulueta, R.C., Hinzman, L., and Kane, D., 2000, Acclimation of ecosystem $\mathrm{CO}_{2}$ exchange in the Alaskan Arctic in response to decadal climate warming: Nature, v, 406, p. 978-981. 
Paustian, K., Elliott, E.T. and Killian, K. 1998, Modeling soil carbon in relation to management and climate change in some agroecosystems in central North America, in Lal, R., Kimble, J., Follett, R.F., and Stewart, B.A. (eds.), Soil Processes and the Carbon Cycle, Advances in Soil Science: Boca Raton, Fla., Lewis Publishers, CRC Press, p. 459-471.

Rabenhorst, M.C., 1995, Carbon storage in tidal marsh soils, in Lal, R., Kimble, J., Levine, E., and Stewart, B.A. (eds.), Soils and Global Change, Advances in Soil Science: Boca Raton, Fla., Lewis Publishers, CRC Press, p. 93-103.

Seybold, C.A., Mausbach, M.J., Karlen, D.L., and Rogers, H.H., 1998, Quantification of soil quality, in Lal, R., Kimble, J., Follett, R.F., and Stewart, B.A. (eds.), Soil Processes and the Carbon Cycle, Advances in Soil Science: Boca Raton, Fla., Lewis Publishers, CRC Press, p. 387-404.

Stewart, B.A., 1995, Soil management in semiarid regions, in Lal, R., Kimble, J., Levine, E., and Stewart, B.A. (eds.), Soil Management and Greenhouse Effect, Advances in Soil Science: Boca Raton, Fla., Lewis Publishers, CRC Press, p. 251-258.

U.S. Geological Survey, 2000, Federal and Indian Lands of the United States: The National Atlas, Reston, Va. [http://nationalatlas.gov/fedlandsm.html], file fedlanp020, accessed November 10, 2000.

Vogelmann, J., Sohl, T., and Howard, S., 1998. Regional characterization of land cover using multiple sources of data: Photogrammetric Engineering and Remote Sensing, v. 64, no. 1, p. $45-57$.

\section{Appendix A: Soil organic carbon calculations in STATSGO}

The soil organic carbon (SOC) for each map unit was calculated by the methods of Bliss and others (1995). The calculations were made for three depth ranges: 0-30 cm, 0-100 cm, and the total profile. The results shown on maps in this paper are for the total profile.

The STATSGO database has a relational database structure, as described in section A1. A series of calculations are used to create an estimate of the SOC by layer, component, and map unit, as shown in section A2, for the total profile. Modifications of the method to calculate SOC for fixed-depth ranges are given in section A3.

The map unit estimates are expressed as carbon intensity in terms of grams of carbon per square meter, suitable for display on a map. The carbon intensities are multiplied by the area to get estimates of the total amount of carbon, reported in tables and the subtitles of maps.

The calculation of carbon intensities was made using the tables in the relational database. For Alaska, a vector version of STATSGO was used, and a vector overlay was created with the Federal lands coverage. For the conterminous United States, a gridded version of STATSGO with a $1 \mathrm{~km}$ cell size was used for the overlay with the Federal lands data and for attaching proportions of land cover classes as discussed in section 2.6. The gridding process used the STATSGO map unit with the dominant area in the grid cell. 


\section{A1. The STATSGO data structure}

The basic STATSGO data structure is given in figure A1. The analysis of soil organic carbon

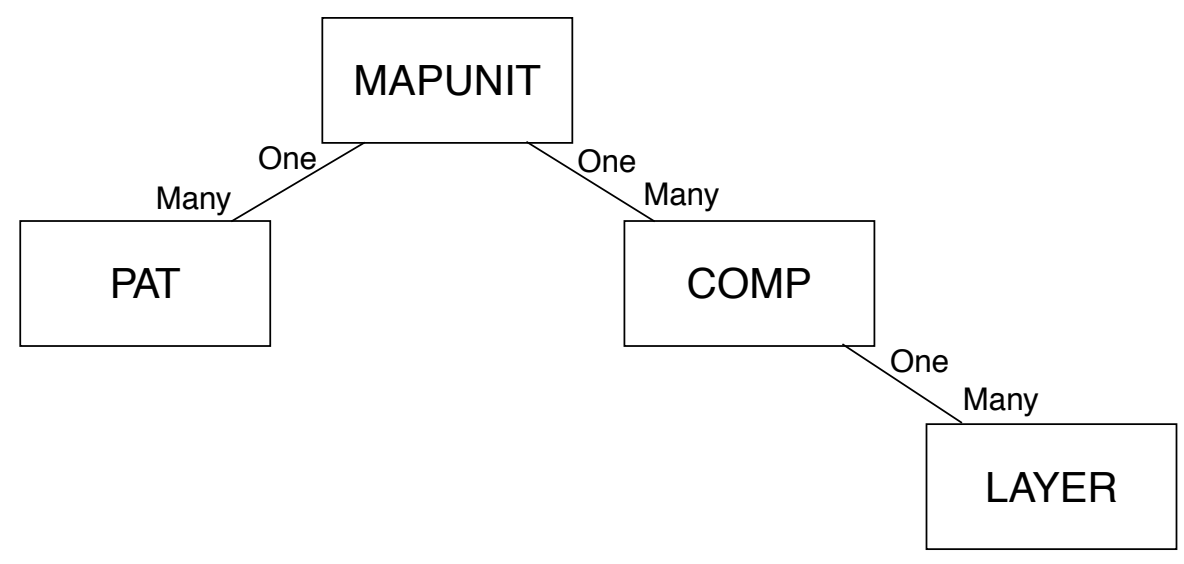

Figure A1. Data structure for selected STATSGO attribute tables. The MAPUNIT table contains attribute information for map units, which are equivalent to soil associations. A map unit may be represented with many polygons on the map. Each polygon is represented with one record in the polygon attribute table (PAT). Each map unit may consist of 1 to 21 components, which are often equivalent to soil series. Each component has a record on the COMP table. Each component may have one or more layers, for which information is coded by depth in the soil. Each layer has a record on the LAYER table. Care must be taken in an analysis to follow the linkages shown here. For example, it is not legitimate to link the COMP table directly to the PAT table.

starts on the LAYER table, aggregates the carbon over the appropriate layers for a given analysis, and stores the result on the component table (COMP). A weighted average of the component values is computed using the component percentage (COMPPCT) as the area weighting factor, and the results are stored on the MAPUNIT table. These results are coded into distinct mapping categories using a lookup table and then copied to the polygon attribute table (PAT), where they are used to plot the map.

\section{A1.1 STATSGO layer data (the LAYER table)}

The attributes from the layer table that are used in the SOC analysis are measures of depth, particle size distribution, bulk density, and organic matter. The layer records are a generalized representation of the soil horizon information obtained when a soil is sampled in the field. Bedrock layers are excluded from the SOC analysis. The thickness of the layer is calculated from the depths. The rock content is calculated from the particle size information. The organic matter percentages are converted to the carbon content by multiplying by a constant. If the bulk density value for an organic soil was missing, the estimate of $0.4 \mathrm{~g} \mathrm{~cm}^{-3}$ was used as a representative value (Sharon Waltman, NRCS, personal communication). The soil texture codes are useful for identifying organic layers and bedrock. 


\section{A1.2 STATSGO component data (the COMP table)}

The component name (COMPNAME) is generally a soil series name. The component name may also represent miscellaneous land types, such as "rubble land," "dune land," or "rough mountainous land." The SOC calculation uses data for the component percentage (which add to 100 percent for the map unit). Although they are not used in the SOC calculation, it is often useful to view the low and high values for the range of slope percentage (rise divided by run) and the surface texture (repeated from the surface layer in the LAYER table) to understand the patterns of SOC on the landscape.

\section{A1.3 STATSGO map unit data (the MAPUNIT table)}

The map unit identifier (MUID) is used as a key variable for linking the tables in the relational data structure. No other attributes are used from the MAPUNIT table, but this level of the data structure is essential for transferring results from the layer and component levels to the polygon attribute table.

\section{A2. Calculations for the total profile}

The calculation of soil organic carbon from STATSGO follows the approach of Bliss and others (1995). The equations presented here may be used to calculate the total carbon in the profile, or subsets of this according to a depth range (for example, 0 to $100 \mathrm{~cm}$ depth) or other analysis zones. The total carbon for the study area $\left(C_{S}, \mathrm{~g} \mathrm{C}\right)$ is the sum of the average carbon intensity of each of the map units $\left(C_{M}, \mathrm{~g} \mathrm{C} \mathrm{m}^{-2}\right)$ times the area of the map unit $\left(A_{M}, \mathrm{~m}^{2}\right)$.

$$
C_{S}=\sum_{M} C_{M} A_{M}
$$

For the purposes of this paper, the carbon intensity is the mass of carbon in the part of the profile under consideration per unit of surface area. For summaries, the units of mass are represented in teragrams $\left(1 \mathrm{Tg}=10^{12} \mathrm{~g}\right)$ or petagrams $\left(1 \mathrm{Pg}=10^{15} \mathrm{~g}\right)$, and area units are in square kilometers $(1$ $\left.\mathrm{km}^{2}=10^{6} \mathrm{~m}^{2}\right)$.

As shown in figure A1, each STATSGO map unit may consist of one or more components. The percentage of the area of each component with respect to the area of the map unit is recorded in the COMPPCT variable on the component (COMP) table. The component percentages within a map unit sum to 100 percent. The component proportions $\left(P_{C}\right.$, component percentage divided by 100 percent) sum to 1 .

$$
1=\sum_{C} P_{C}
$$

The carbon intensity of a map unit is the weighted sum of the carbon intensities of the components, where the component proportion is the weighting factor.

$$
C_{M}=\sum_{C} C_{C} P_{C}
$$

Map units or components are given a zero carbon content if they represent nonsoil (water, gravel 
pit, rock outcrop, urban land, and so on). There is not necessarily a record in the LAYER table for a nonsoil component.

The carbon intensity of a component $\left(C_{C}, \mathrm{~g} \mathrm{C} \mathrm{m}^{-2}\right)$ is the sum of the carbon intensities of the layers $\left(C_{L}, \mathrm{~g} \mathrm{C} \mathrm{m}^{-2}\right)$.

$$
C_{C}=\sum_{L} C_{L}
$$

Nonsoil layers (such as bedrock) are treated as having zero carbon.

The carbon intensity of the layer is calculated as the product:

$$
C_{L}=O D R T
$$

where

$O=$ Organic carbon content,

$D=$ Bulk density,

$R=$ Rock fragment conversion factor, and

$T=$ Thickness of the layer.

The organic carbon content represents the mass of carbon per mass of soil fines. Multiplying by the bulk density changes the basis to the volume of soil fines. Multiplying by the rock fragment conversion factor changes the basis to the total volume of the soil under moist conditions, as would be expected in the field. Multiplying by the thickness of the layer changes from a volume basis to a surface area basis, appropriate for aggregation to the component, map unit, and study area as in equations A4, A3, and A1.

The calculations in equation A5 make use of the following STATSGO variables:

OML organic matter, low (minimum of range, percentage by weight)

$\mathrm{OMH} \quad$ organic matter, high (maximum of range, percentage by weight)

BDL bulk density, low (minimum of range, $\mathrm{Mg} \mathrm{m}^{-3}$ )

$\mathrm{BDH} \quad$ bulk density, high (maximum of range, $\mathrm{Mg} \mathrm{m}^{-3}$ )

INCH10L minimum percentage by weight of rock fragments $>10$ inches $(25 \mathrm{~cm})$, whole soil basis

INCH10H maximum percentage by weight of rock fragments $>10$ inches $(25 \mathrm{~cm})$, whole soil basis

INCH3L minimum percentage by weight of rock fragments 3 to 10 inches (7.5 to 25 $\mathrm{cm})$, whole soil basis

INCH3H maximum percentage by weight of rock fragments 3 to 10 inches (7.5 to 25 $\mathrm{cm})$, whole soil basis

NO10L minimum percentage by weight passing No. 10 sieve ( $2 \mathrm{~mm}$ sieve size; on the basis of soil $<7.5 \mathrm{~cm}$ )

$\mathrm{NO10H}$ maximum percentage by weight passing No. 10 sieve $(2 \mathrm{~mm}$ sieve size; on the basis of soil $<7.5 \mathrm{~cm}$ ) 
LAYDEPL layer depth, low, (upper boundary of soil layer; inches)

LAYDEPH layer depth, high, (lower boundary of soil layer; inches)

Some manipulations of these variables are needed to calculate the terms of equation A5.

The organic carbon content $\left(O, \mathrm{~g} \mathrm{C} \mathrm{g}^{-1}\right.$ soil fines $)$ in equation $\mathrm{A} 5$ is computed by multiplying the midpoint organic matter by two conversion factors:

$$
O=(0.01)(0.58)(\mathrm{OML}+\mathrm{OMH}) / 2
$$

The OML and OMH variables represent grams of organic matter per 100 grams of soil. This is also known as the percentage of organic matter in the fine soil fraction ( $<2 \mathrm{~mm}$ particle diameter). The average of the low and high estimates is multiplied by 0.01 to convert from a $100-\mathrm{g}$ basis to a 1 -g basis. The organic matter value is converted to a measure of organic carbon by multiplying by 0.58 (method 6A, NRCS Soil Survey Staff, 1996).

The bulk density factor $\left(D, \mathrm{~g}_{\text {soil fines }} \mathrm{m}^{-3}\right.$ soil fines $)$ in equation $\mathrm{A} 5$ is used to change the measure of carbon content from a mass basis (appropriate for the laboratory) to a volume basis (appropriate for a geographic information system).

$$
D=(1,000,000)(\mathrm{BDL}+\mathrm{BDH}) / 2
$$

The standard units for bulk density used for BDL and BDH, $\mathrm{Mg} \mathrm{m}^{-3}$, are multiplied by 1,000,000 $\mathrm{g} \mathrm{Mg}^{-1}$ to convert from megagrams to grams. Alternatively, the units for bulk density can be considered to be $\mathrm{g} \mathrm{cm}^{-3}$, and the conversion factor represents $1,000,000 \mathrm{~cm}^{3} \mathrm{~m}^{-3}$. The average of the low and high bulk density estimates is used.

The rock fragment conversion factor $\left(R, \mathrm{~m}^{3}\right.$ soil fines $\mathrm{m}^{-3}$ soil $)$ in equation $\mathrm{A} 5$ is computed as the ratio of the volume of soil fines to the volume of the total soil (Method 3B2, NRCS Soil Survey Staff, 1996). This conversion factor was not provided in the STATSGO data but is computed from available measures.

$$
\begin{aligned}
R & =\text { Rock fragment conversion factor }=\frac{\text { Volume moist }<2 \text { mm fabric }}{\text { Volume moist whole soil }} \\
& =\frac{V_{\text {fines }}}{V_{\text {fines }}+V_{\text {rock }}}=\frac{\left(M_{f}\right) /\left(D_{b}\right)}{\left(M_{f}\right) /\left(D_{b}\right)+\left(M_{r}\right) /\left(D_{p}\right)}=\frac{\left(R_{f t}\right) /\left(D_{b}\right)}{\left(R_{f t}\right) /\left(D_{b}\right)+\left(R_{r t}\right) /\left(D_{p}\right)}
\end{aligned}
$$

where

$$
\begin{aligned}
R_{f t} & =\left(R_{f s}\right)\left(R_{s t}\right) \\
R_{f s} & =(\mathrm{NO} 10 \mathrm{~L}+\mathrm{NO} 10 \mathrm{H}) / 200 \\
R_{s t} & =1-R_{y t}-R_{z t} \\
R_{y t} & =(\mathrm{INCH} 3 \mathrm{~L}+\mathrm{INCH} 3 \mathrm{H}) / 200 \\
R_{z t} & =(\mathrm{INCH} 10 \mathrm{~L}+\mathrm{INCH} 10 \mathrm{H}) / 200
\end{aligned}
$$




$$
\begin{aligned}
& D_{b}=(\mathrm{BDL}+\mathrm{BDH}) / 2 \\
& R_{r t}=1-R_{f t} \\
& D_{p}=2.65 \mathrm{Mg} \mathrm{m}^{-3}
\end{aligned}
$$

The data values in STATSGO represent estimates of laboratory measures and are reported on the basis of the mass $\left(M_{f}\right)$ of the fine soil fraction (less than 2-mm diameter). The mass of rocks $\left(M_{r}\right)$ represents all rocks greater than $2 \mathrm{~mm}$. The conversion factor $(R)$ is expressed in terms of soil volumes, but the values reported in the STATSGO database are in terms of mass percentages. Dividing the masses $\left(M_{f}\right.$ and $\left.M_{r}\right)$ by the total mass of the soil allows the conversion factor to be defined in terms of $R_{f t}$, the ratio of the mass of soil fines to the total mass of the soil, and $R_{r t}$, the ratio of the mass of rock to the total mass. The bulk density of the soil fines $\left(D_{b}\right)$ and the particle density of rock $\left(D_{p}\right)$ are used to convert each fraction to a volume basis. The mass ratio of soil fines to the total soil $\left(R_{f t}\right)$ is computed as the product of the mass ratio of soil fines to the sampled (less than $3 \mathrm{inch}$ ) soil $\left(R_{f_{s}}\right)$ and the mass ratio of the sampled soil to the total soil $\left(R_{s t}\right)$. The ratio $R_{f s}$, is represented in the STATSGO data items NO10L and NO10H, which are averaged and converted from a percentage basis to a proportion. The percentage of the total soil mass that is rocks between 3 and 10 inches is reported in the data items INCH3L and INCH3H. Similarly, the percentage of the total soil mass that is rocks greater than 10 inches in diameter and less than the size of the pedon is reported in the data items INCH10L and INCH10H. These are expressed as mass ratios $\left(R_{y t}\right.$ and $\left.R_{z t}\right)$ to the whole soil basis, and the mass fraction of the sampled soil $\left(R_{s t}\right)$ is computed by subtraction. The mass fraction of rock $\left(R_{r t}\right)$ is computed by subtracting the proportion of the soil fines $\left(R_{f t}\right)$ from the whole soil (1.0). Tests are included in the calculation to prevent illogical values, such as more than 100-percent rock.

The thickness $(T, \mathrm{~m})$ in equation A5 was used to convert from a carbon density basis $\left(\mathrm{g} \mathrm{C} \mathrm{m}^{-3}\right)$ to a carbon intensity (mass for the layer per unit of surface of area; $\mathrm{g} \mathrm{C} \mathrm{m}^{-2}$ ). The thickness is computed by subtracting the top depth from the bottom depth.

$$
T=(0.0254)(\mathrm{LAYDEPH}-\mathrm{LAYDEPL})
$$

The units are converted using $0.0254 \mathrm{~m} \mathrm{inch}^{-1}$.

The primary results presented in this paper are for the carbon content for the total profile. Several additional results are presented for selected analysis zones that represent subsets of the total profile. These calculations are made by substituting specialized thickness measures for $T$ in equation A9. Specific depth ranges or layers with special properties of interest may be used, and the value of $T$ is set to zero for layers or parts of layers that do not meet the criteria.

\section{A3. Calculations limited to a depth zone}

Total profile calculation in the previous section makes use of data for all layers above bedrock. For intercomparisons with other studies, and to understand the carbon processes in relation to physical and ecological processes, it is useful to also compute soil carbon limited to 0-30 cm and 0-100 depth ranges. 


\section{A3.1 Fixed-depth analysis zones}

For fixed-depth analysis zones, the layer carbon density $\left(\mathrm{g} \mathrm{C} \mathrm{m}^{-3}\right)$ is multiplied by the thickness of the layer within the analysis zone $(\mathrm{m})$ to give a carbon quantity for the layer per unit of surface area $\left(\mathrm{g} \mathrm{C} \mathrm{m}^{-2}\right)$. The process is illustrated in figure $\mathrm{A} 2$.

\begin{tabular}{|c|c|c|c|c|}
\hline & & & & one \\
\hline & & & $0-30 \mathrm{~cm}$ depth & $0-100 \mathrm{~cm}$ depth \\
\hline & $\begin{array}{l}\text { Thickness } \\
(\mathrm{cm})\end{array}$ & $\begin{array}{l}\text { Depth } \\
(\mathrm{cm})\end{array}$ & $\begin{array}{c}\text { Thickness } \\
(\mathrm{cm})\end{array}$ & $\begin{array}{l}\text { Thickness } \\
(\mathrm{cm})\end{array}$ \\
\hline 1 st layer & 40 & & 30 & 40 \\
\hline 2nd layer & 50 & & 0 & 50 \\
\hline 3rd layer & 30 & & 0 & 10 \\
\hline
\end{tabular}

Figure A2. Schematic diagram for layer thickness within a fixed analysis zone, illustrated for the $0-30 \mathrm{~cm}$ depth and 0-100 $\mathrm{cm}$ depth analysis zones of a soil component.

Although it is not shown here, you can also use data items in the selection of analysis zones. For example, an analysis could be limited to organic layers (such as muck or peat), or it could exclude such layers.

\section{Appendix B: Maps}

Figures B1 through B19 contain maps that illustrate patterns of federal land ownership and soil carbon.

Figure B1. Federal and Indian Lands of the United States, plotted from the National Atlas database.

Figure B2. Department of the Interior lands, by Bureau, plotted from the National Atlas database.

Figure B3. Soil organic carbon $\left(\mathrm{kg} \mathrm{C} \mathrm{m}^{-2}\right)$ for all lands in the conterminous United States and Alaska.

Figure B4. Soil organic carbon $\left(\mathrm{kg} \mathrm{C} \mathrm{m}^{-2}\right)$ for all lands in the conterminous United States and Alaska (legend maximum at $80 \mathrm{~kg} \mathrm{C} \mathrm{m}^{-2}$ ).

Figure B5. Soil organic carbon $\left(\mathrm{kg} \mathrm{C} \mathrm{m}^{-2}\right)$ for non-Federal lands in the conterminous United States and Alaska.

Figure B6. Soil organic carbon $\left(\mathrm{kg} \mathrm{C} \mathrm{m}^{-2}\right)$ for Federal lands in the conterminous United States and Alaska.

Figure B7. Soil organic carbon $\left(\mathrm{kg} \mathrm{C} \mathrm{m}^{-2}\right)$ for Federal lands that are not in the Department of the Interior, in the conterminous United States and Alaska. 
Figure B8. Soil organic carbon $\left(\mathrm{kg} \mathrm{C} \mathrm{m}^{-2}\right)$ for Department of the Interior lands in the conterminous United States and Alaska (total profile).

Figure B9. Soil organic carbon $\left(\mathrm{kg} \mathrm{C} \mathrm{m}^{-2}\right)$ for Department of the Interior lands in the conterminous United States and Alaska (0-30 cm depth).

Figure B10. Soil organic carbon $\left(\mathrm{kg} \mathrm{C} \mathrm{m}^{-2}\right)$ for lands of the Department of the Interior's Bureau of Land Management in the conterminous United States and Alaska.

Figure B11. Soil organic carbon $\left(\mathrm{kg} \mathrm{C} \mathrm{m}^{-2}\right)$ for lands of the Department of the Interior's Fish and Wildlife Service in the conterminous United States and Alaska.

Figure B12. Soil organic carbon $\left(\mathrm{kg} \mathrm{C} \mathrm{m}^{-2}\right)$ for lands of the Department of the Interior's National Park Service in the conterminous United States and Alaska.

Figure B13. Soil organic carbon $\left(\mathrm{kg} \mathrm{C} \mathrm{m}^{-2}\right)$ for Indian Trust lands of the Department of Interior's Bureau of Indian Affairs in the conterminous United States and Alaska.

Figure B14. Soil organic carbon $\left(\mathrm{kg} \mathrm{C} \mathrm{m}^{-2}\right)$ for lands of the Department of the Interior's Bureau of Reclamation (BOR) in the conterminous United States. There are no BOR lands in Alaska.

Figure B15. Soil organic carbon $\left(\mathrm{kg} \mathrm{C} \mathrm{m}^{-2}\right)$ for Water, Barren, and Urban areas of the Department of the Interior's land in the conterminous United States.

Figure B16. Soil organic carbon $\left(\mathrm{kg} \mathrm{C} \mathrm{m}^{-2}\right)$ for Forest, Transitional, and Woody Wetland areas of the Department of the Interior's land in the conterminous United States.

Figure B17. Soil organic carbon $\left(\mathrm{kg} \mathrm{C} \mathrm{m}^{-2}\right)$ for Shrubland areas of the Department of the Interior's land in the conterminous United States.

Figure B18. Soil organic carbon $\left(\mathrm{kg} \mathrm{C} \mathrm{m}^{-2}\right)$ for Cropland, Fallow, and Orchard areas of the Department of the Interior's land in the conterminous United States.

Figure B19. Soil organic carbon $\left(\mathrm{kg} \mathrm{C} \mathrm{m}^{-2}\right)$ for Grassland, Pasture, and Emergent Herbaceous Wetland areas of the Department of the Interior's land in the conterminous United States. 


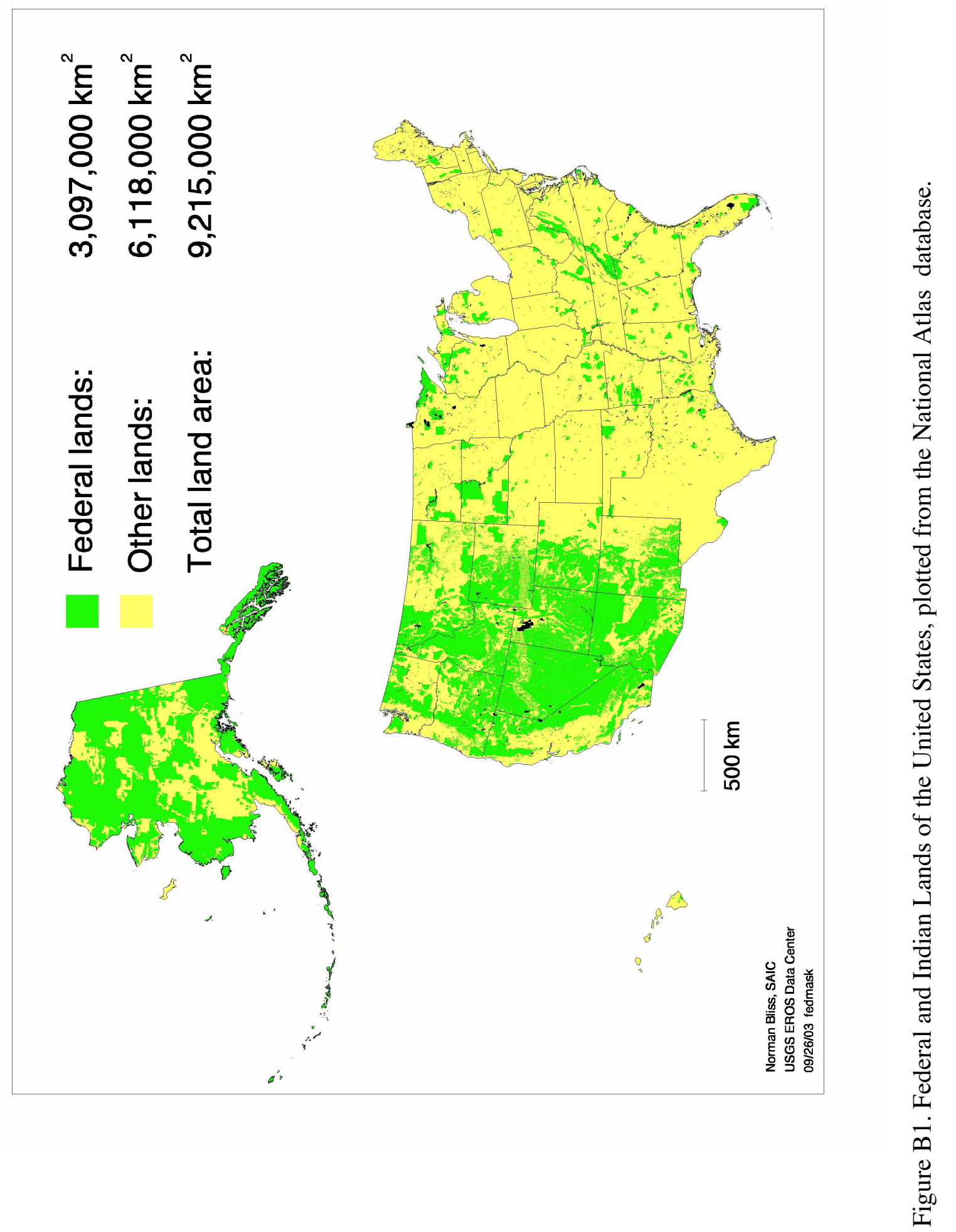




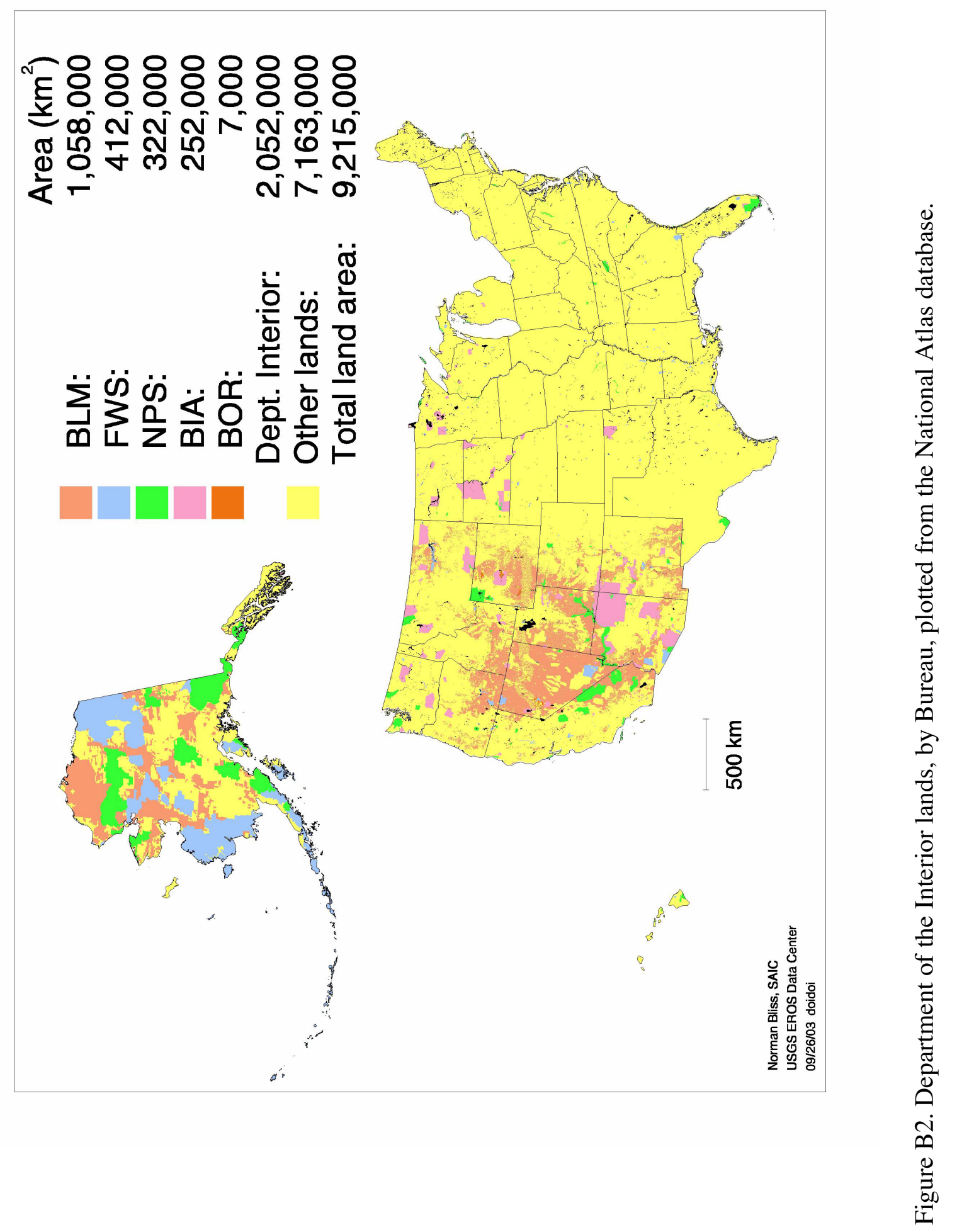




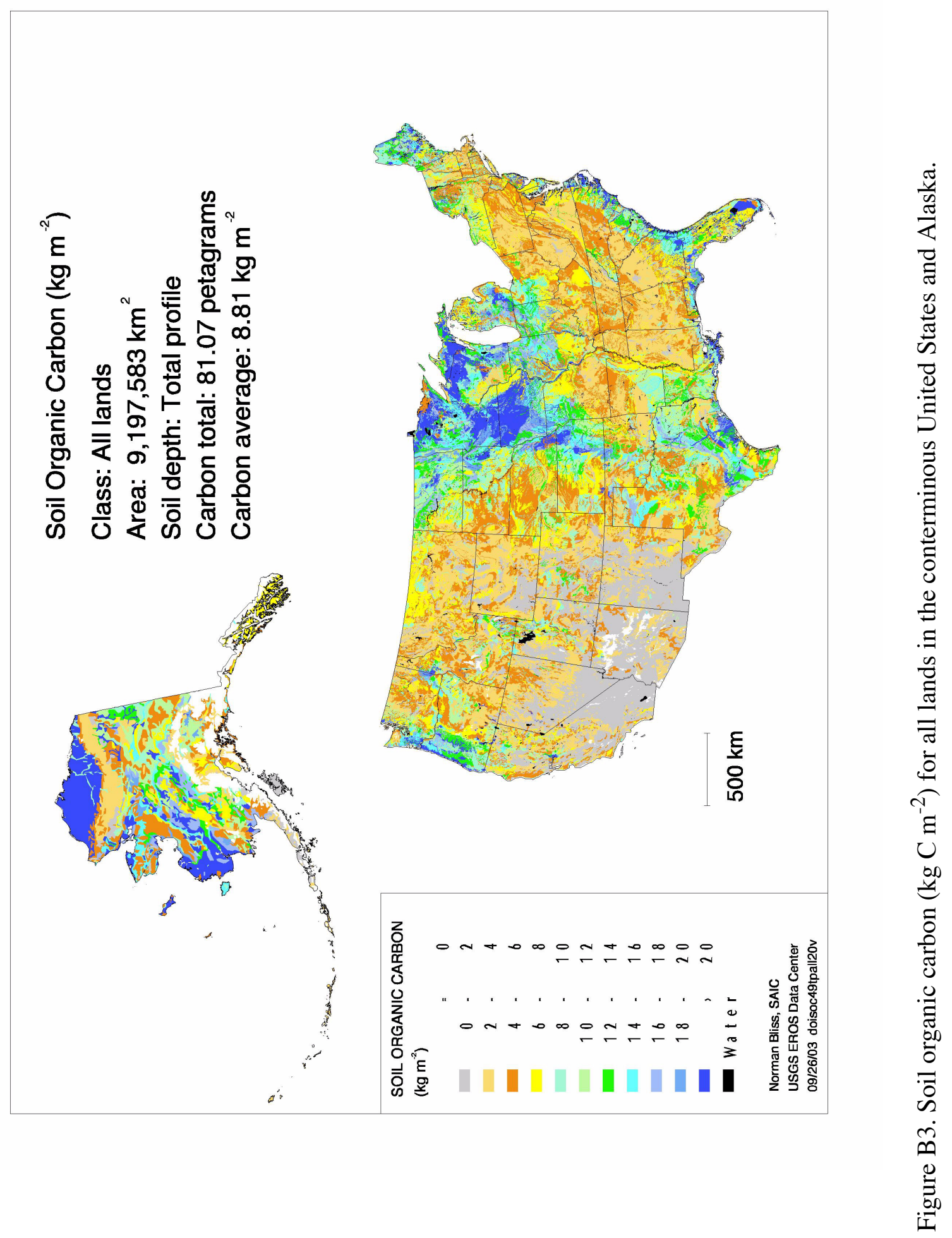




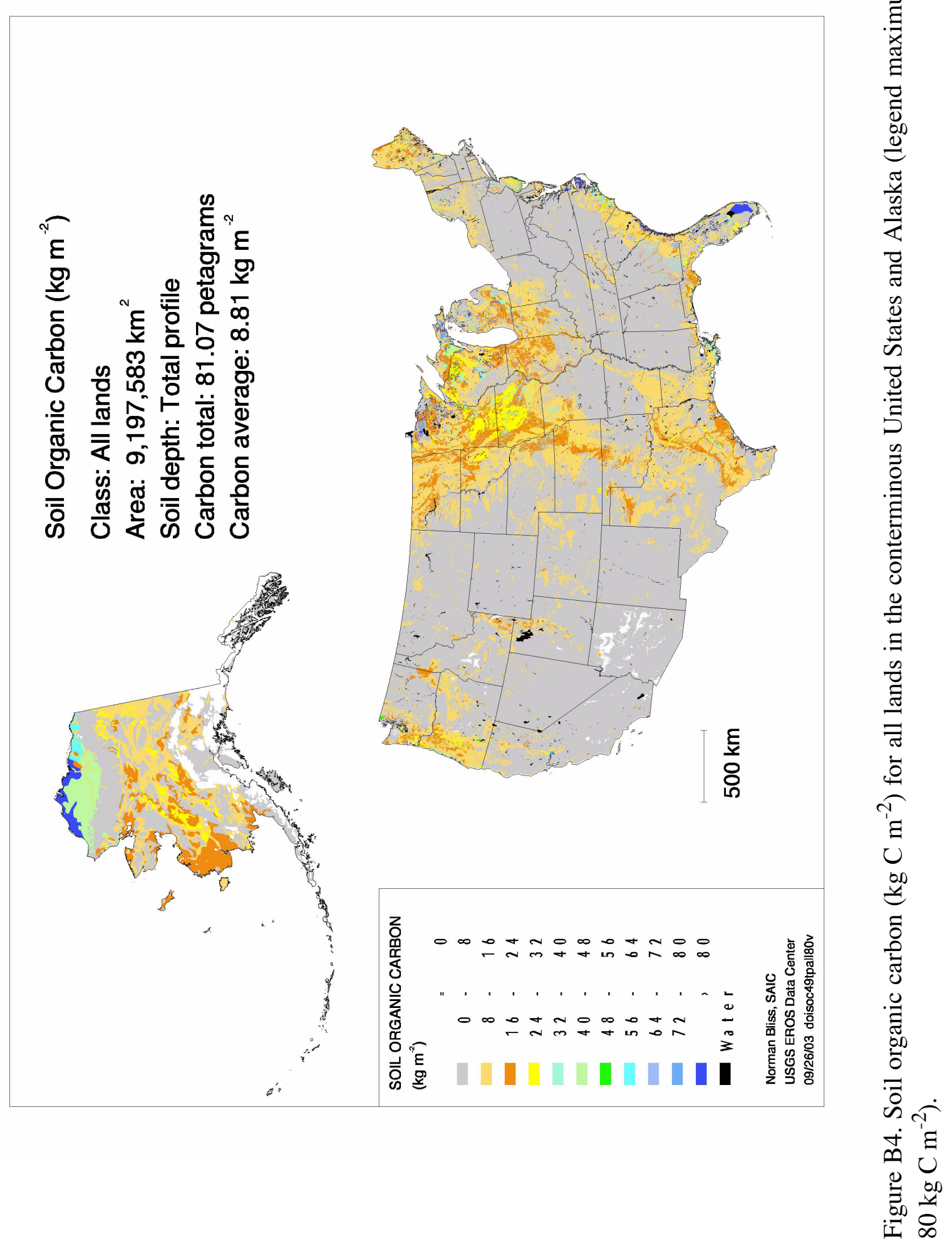




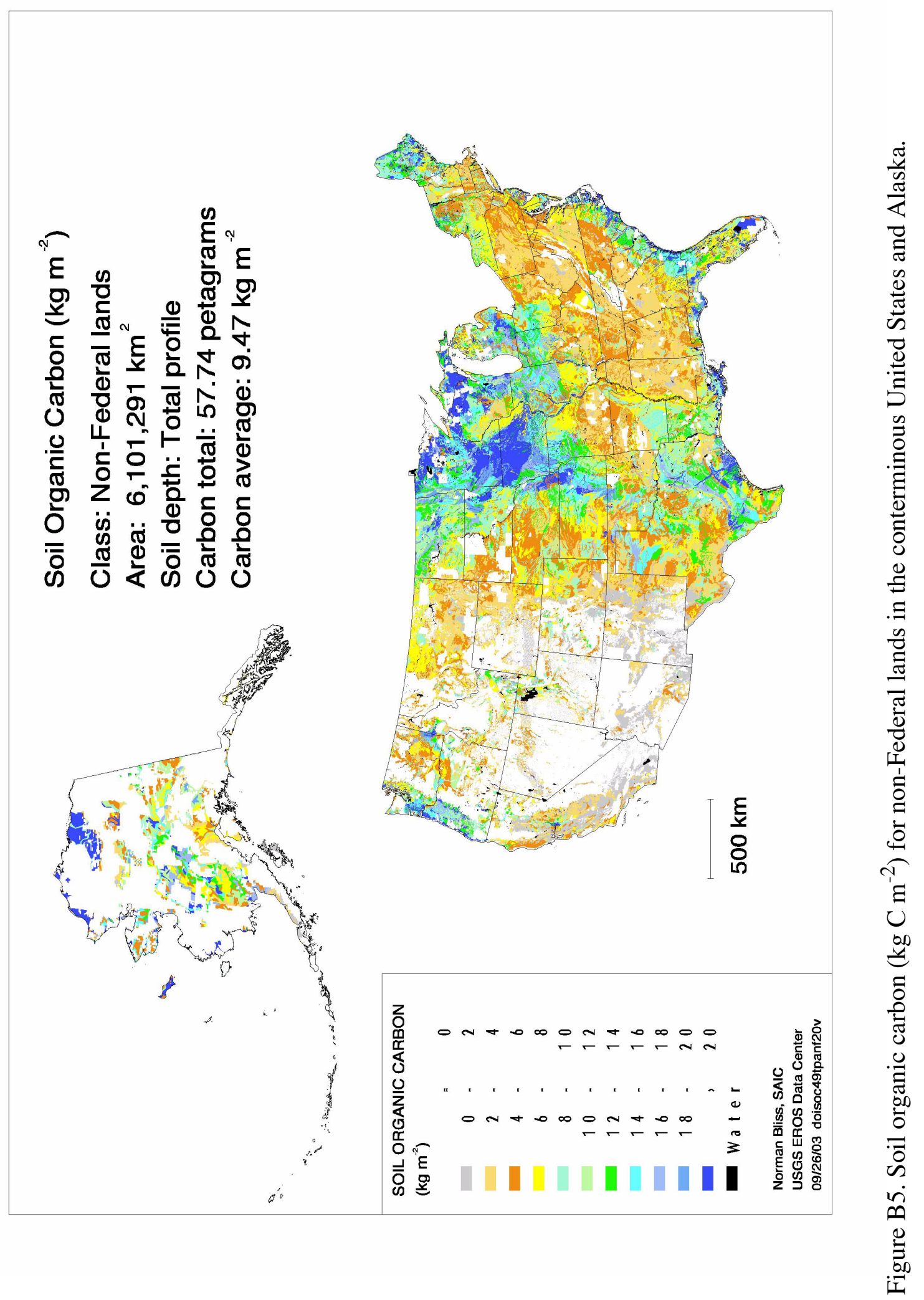




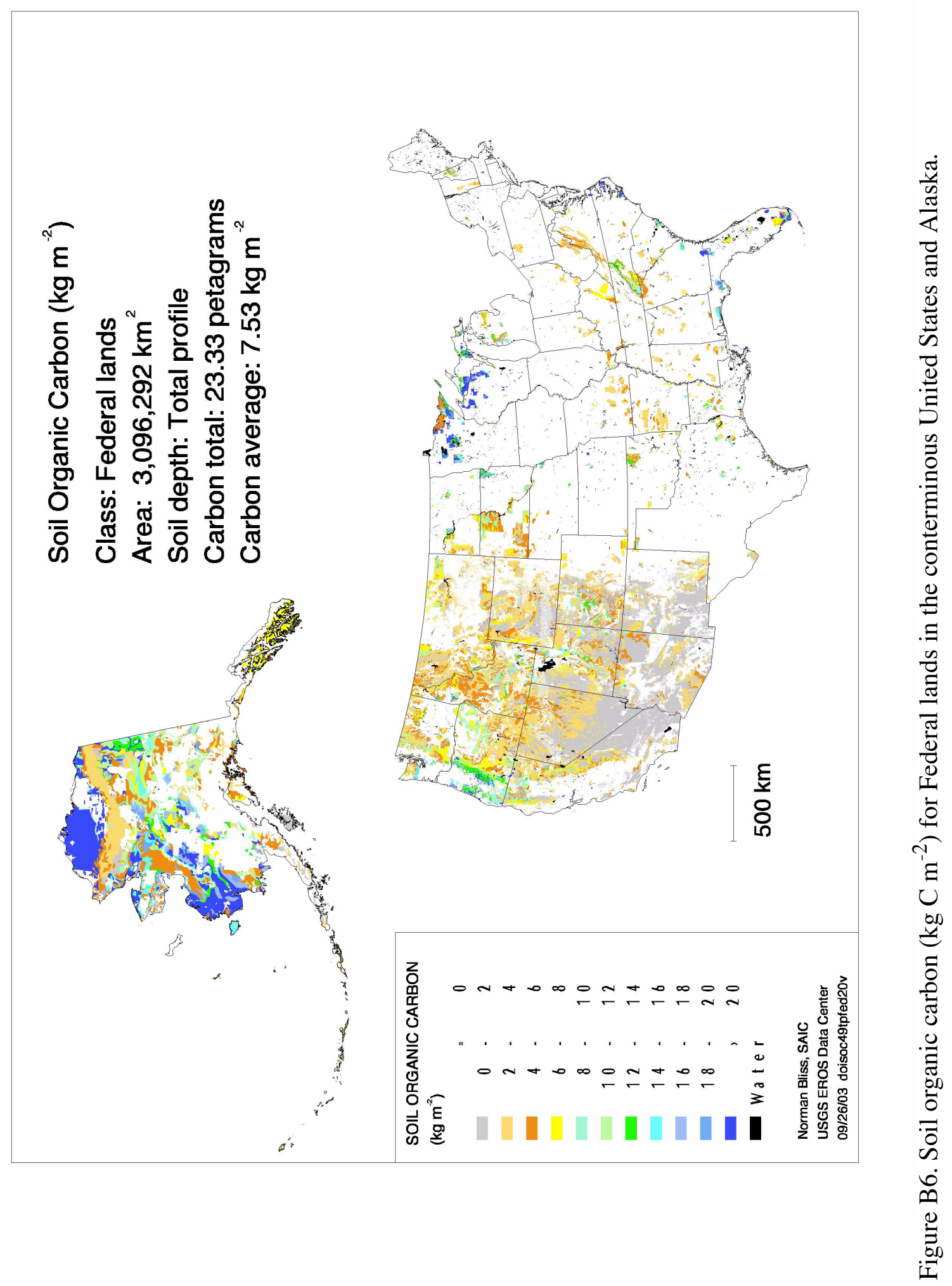




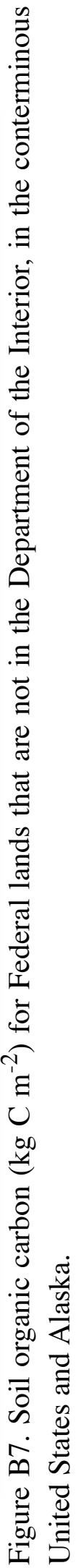




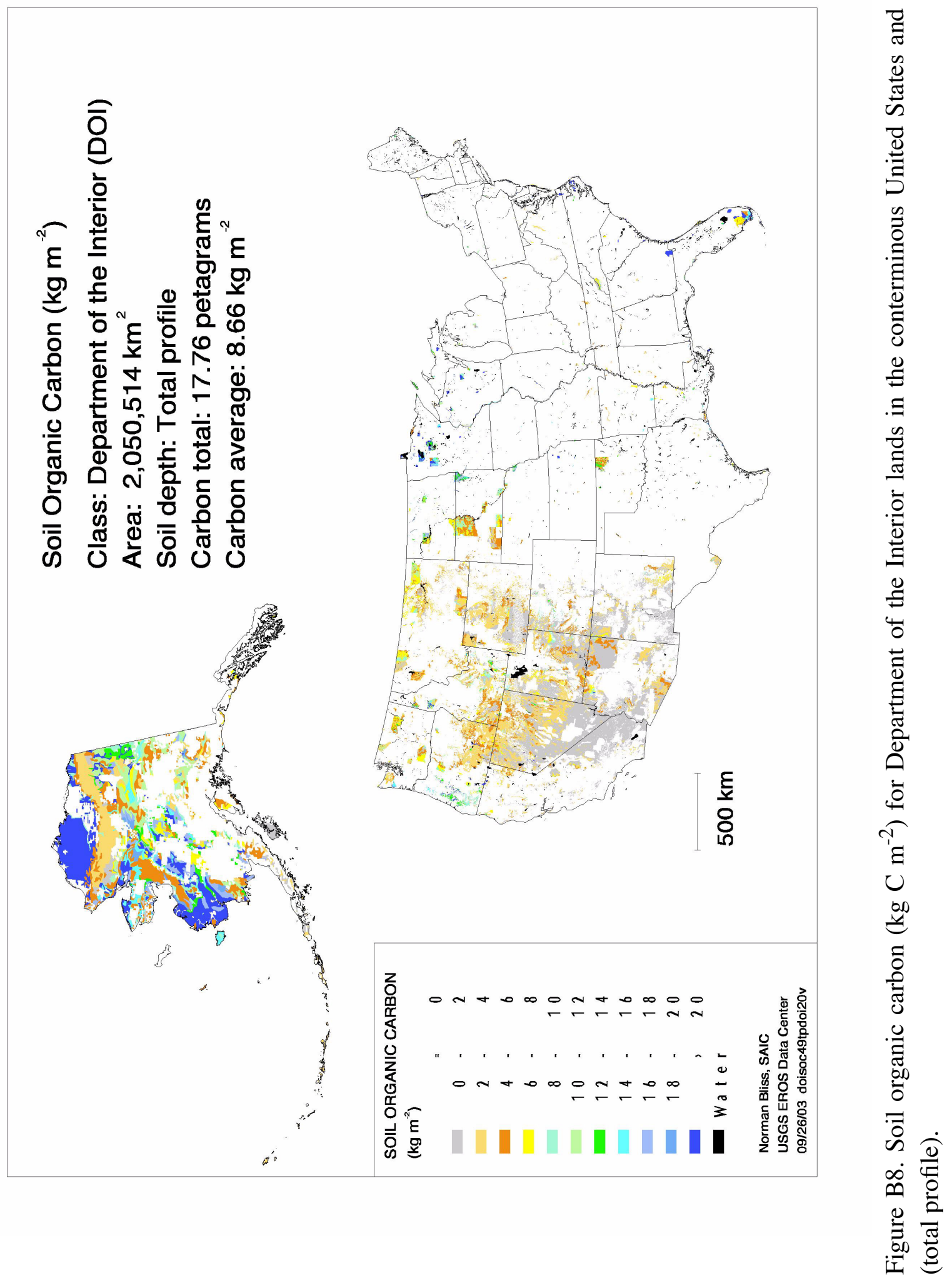




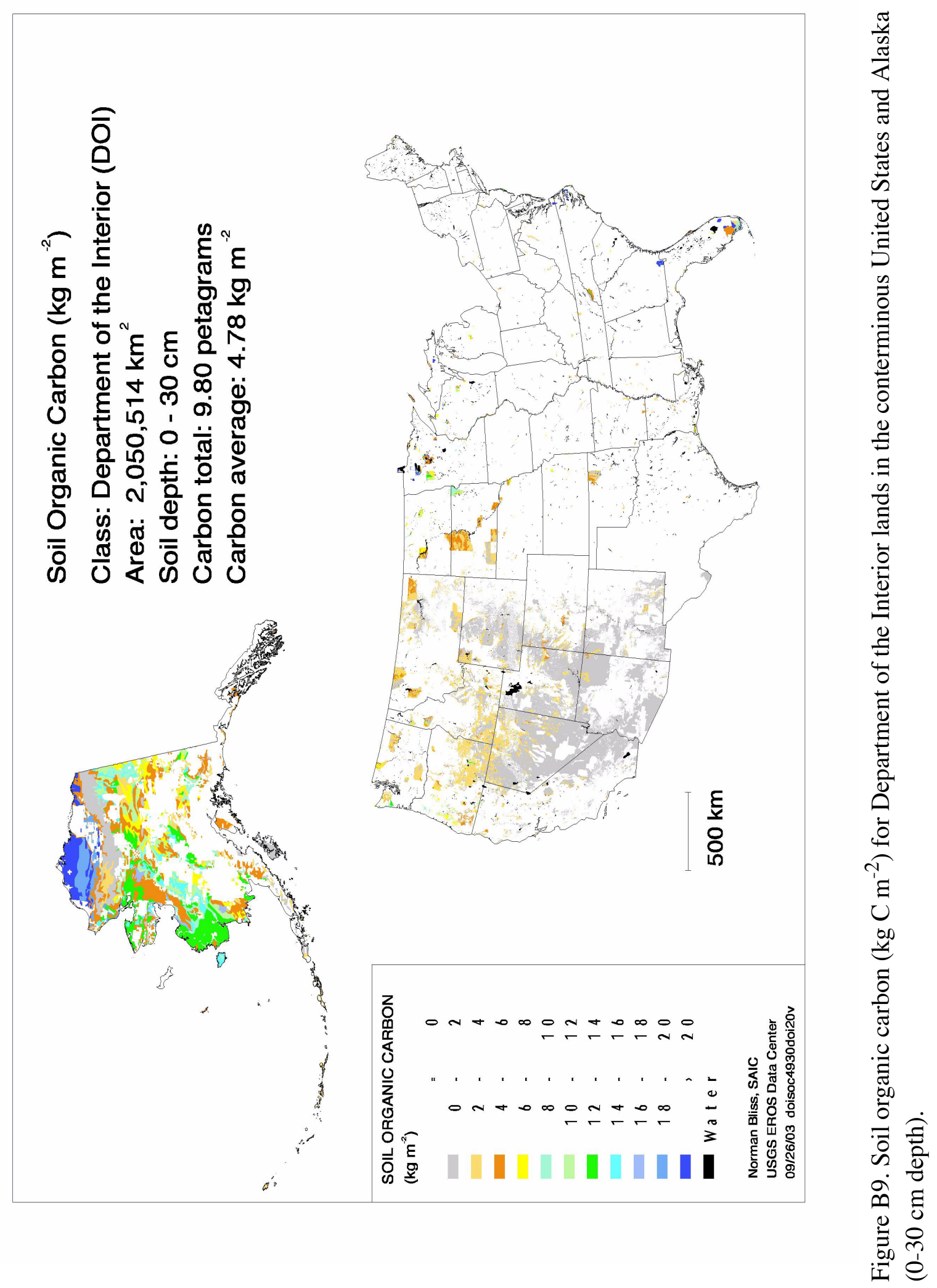




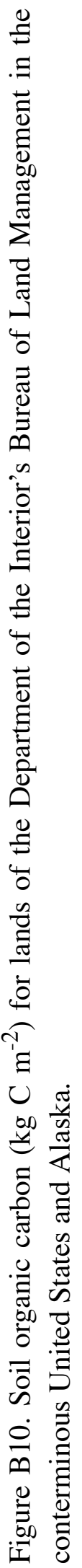




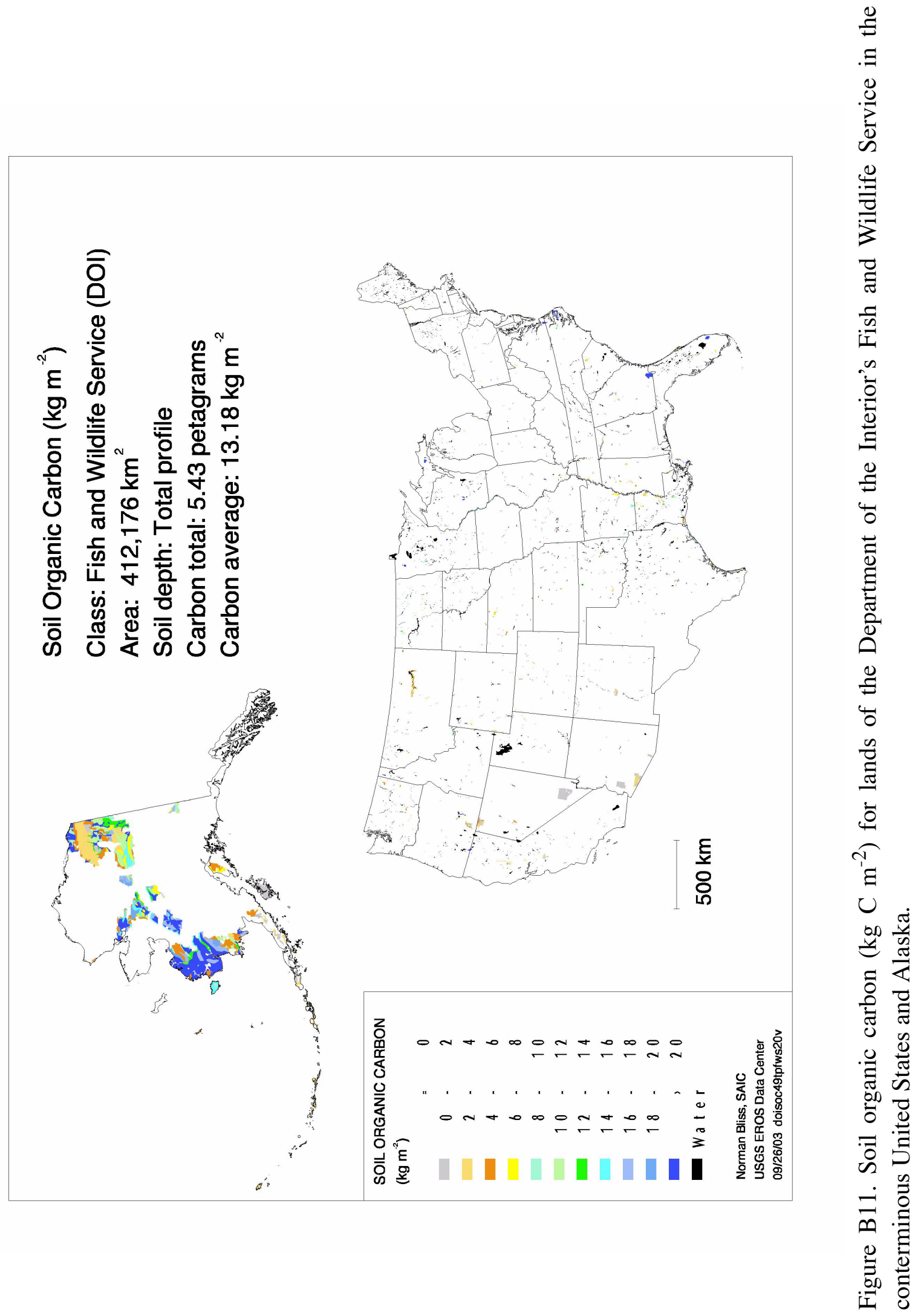




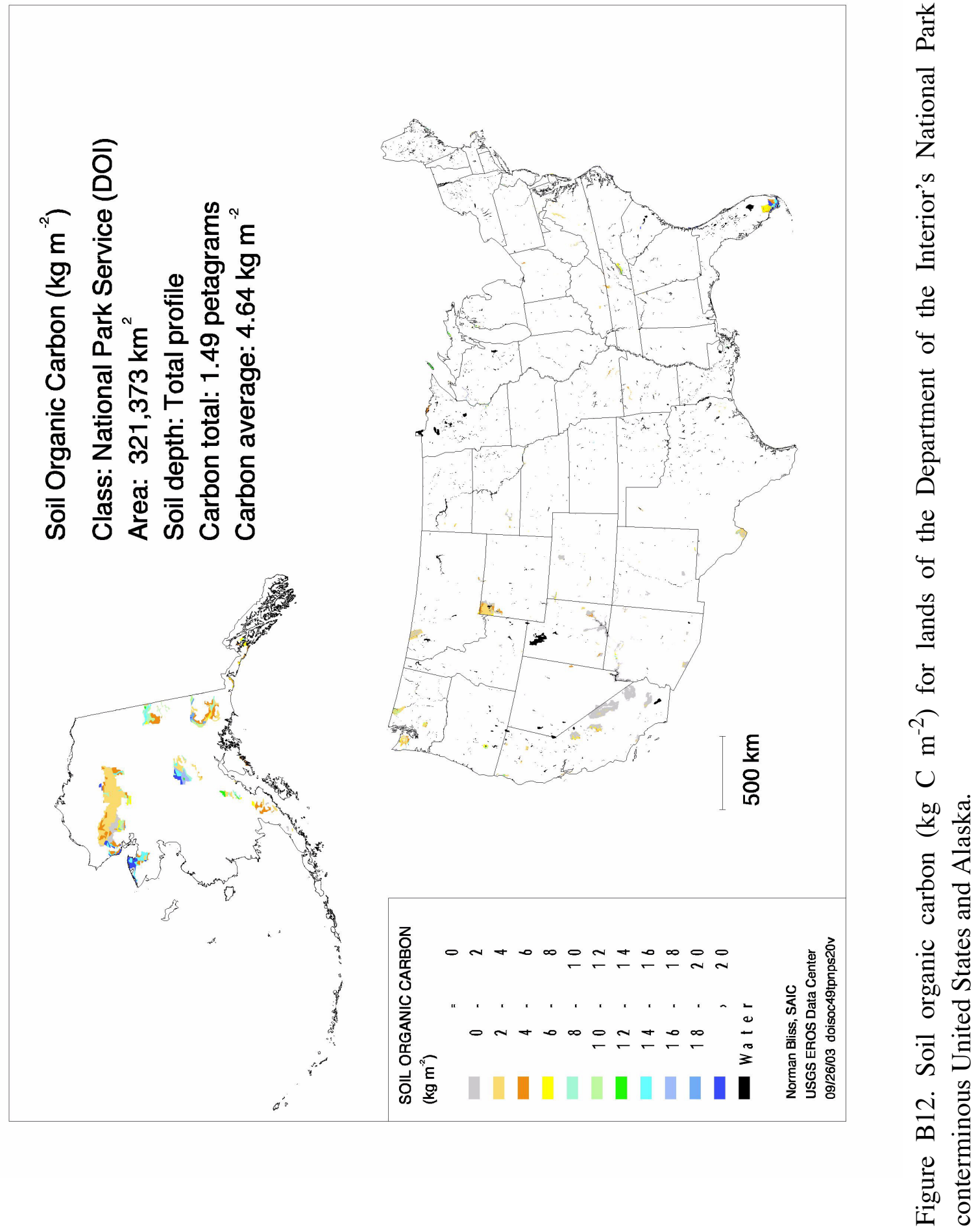




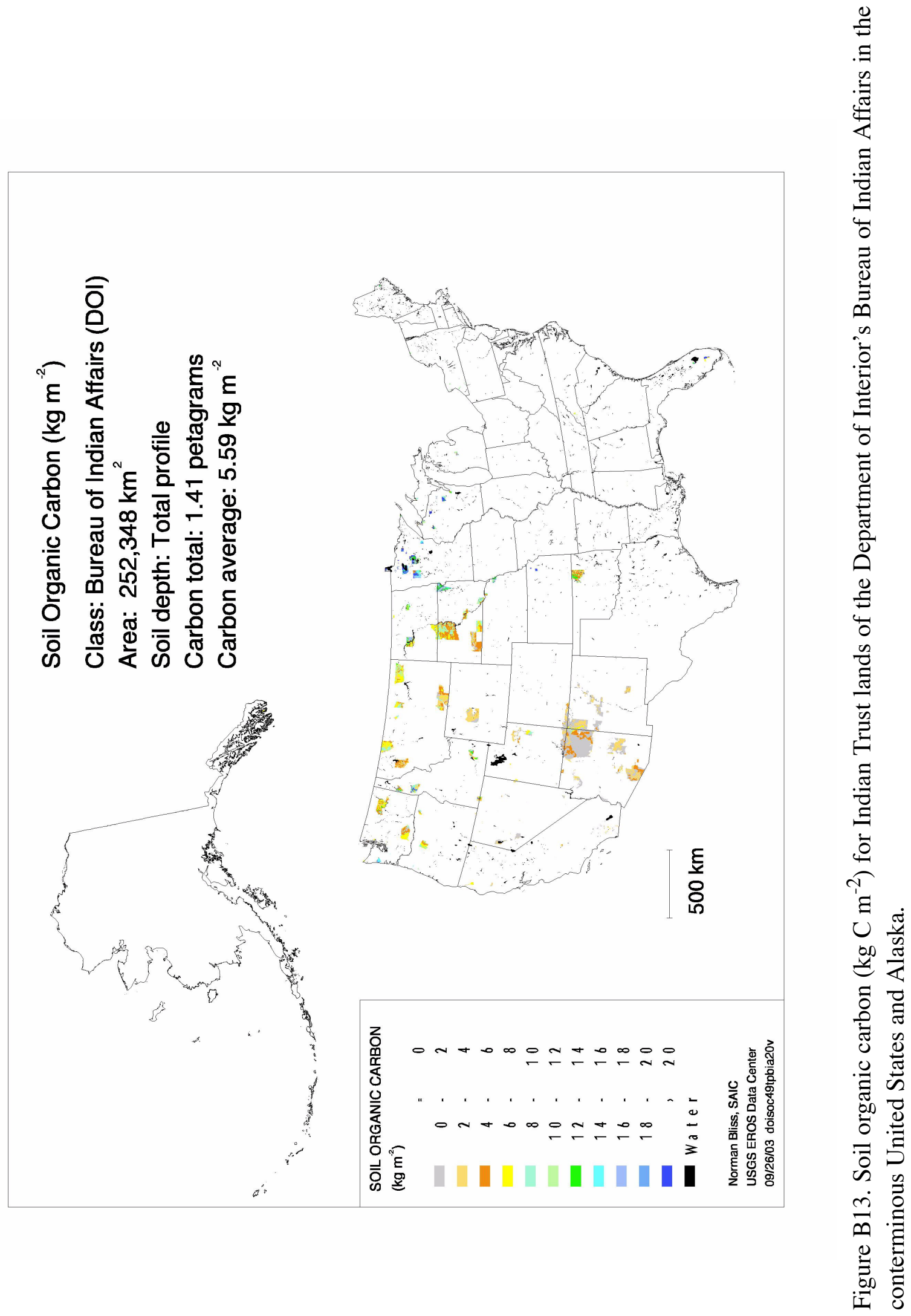




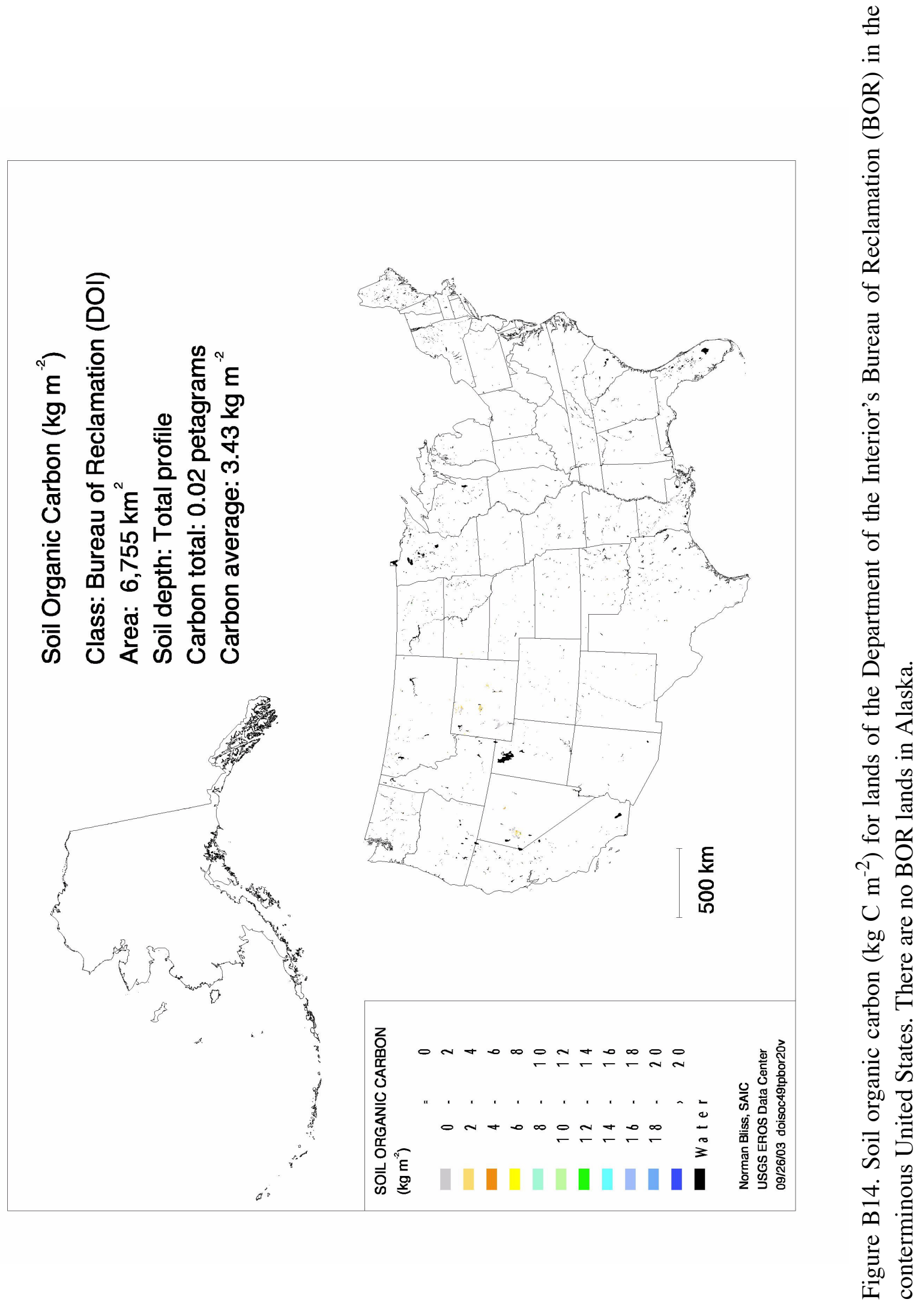



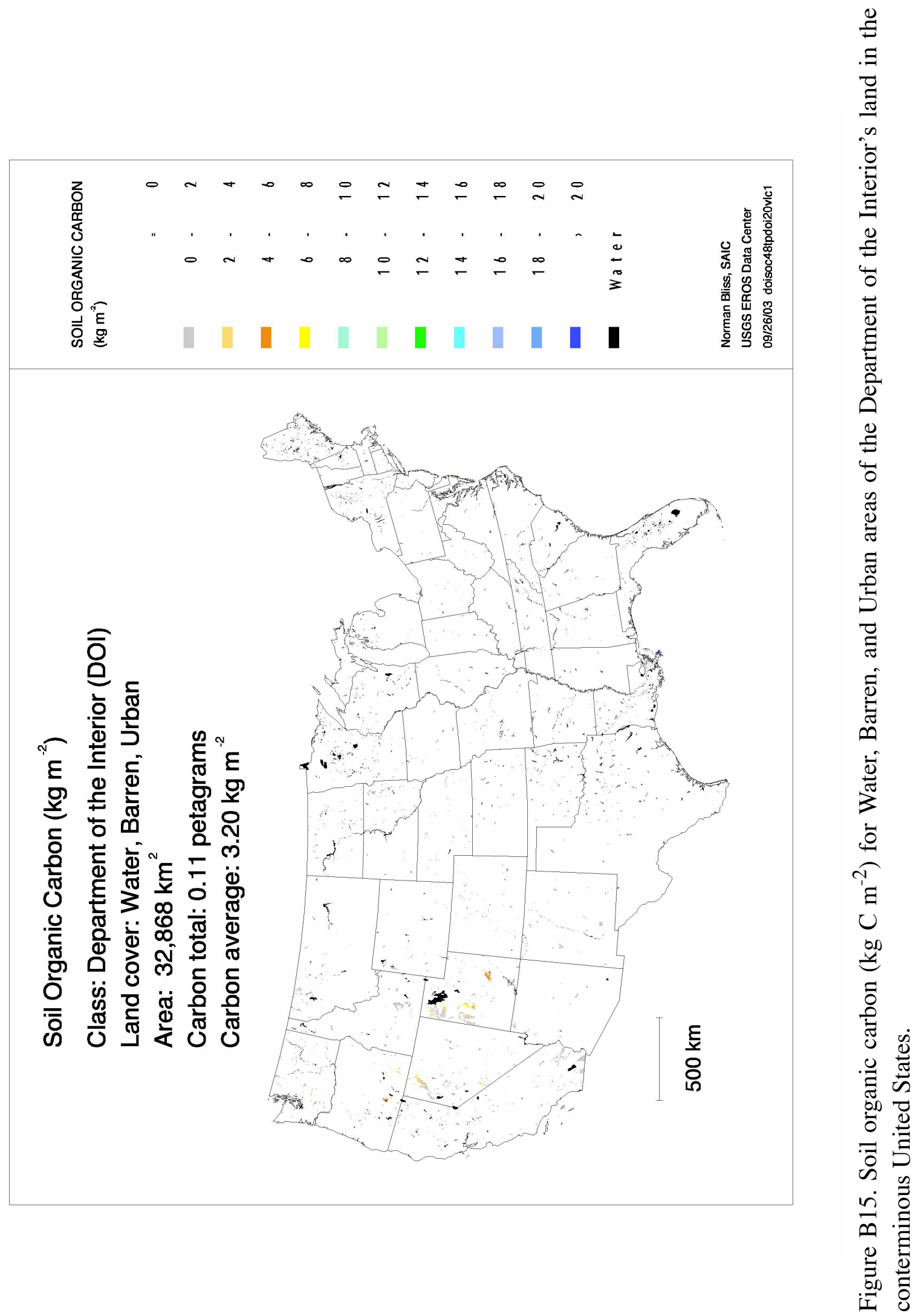


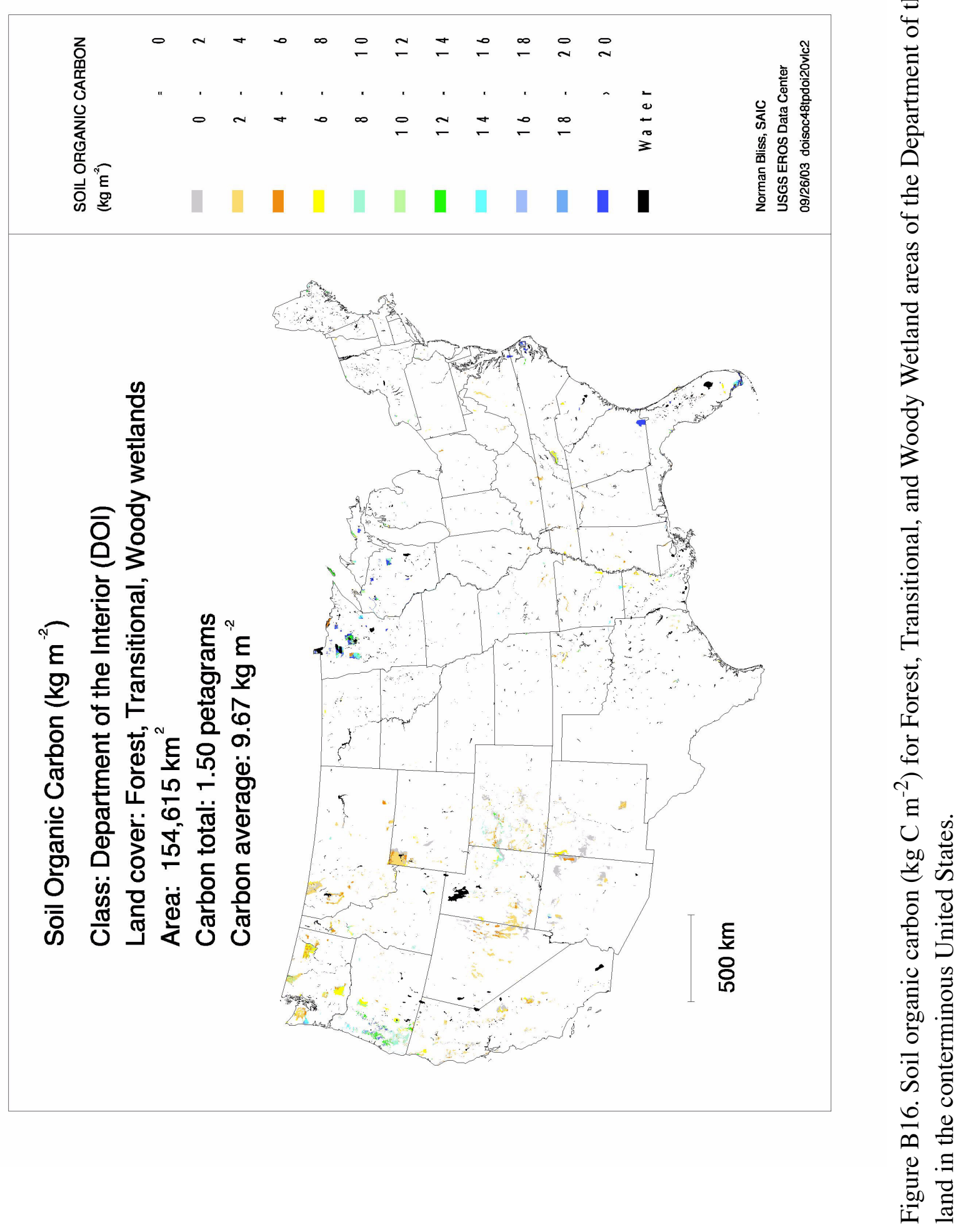




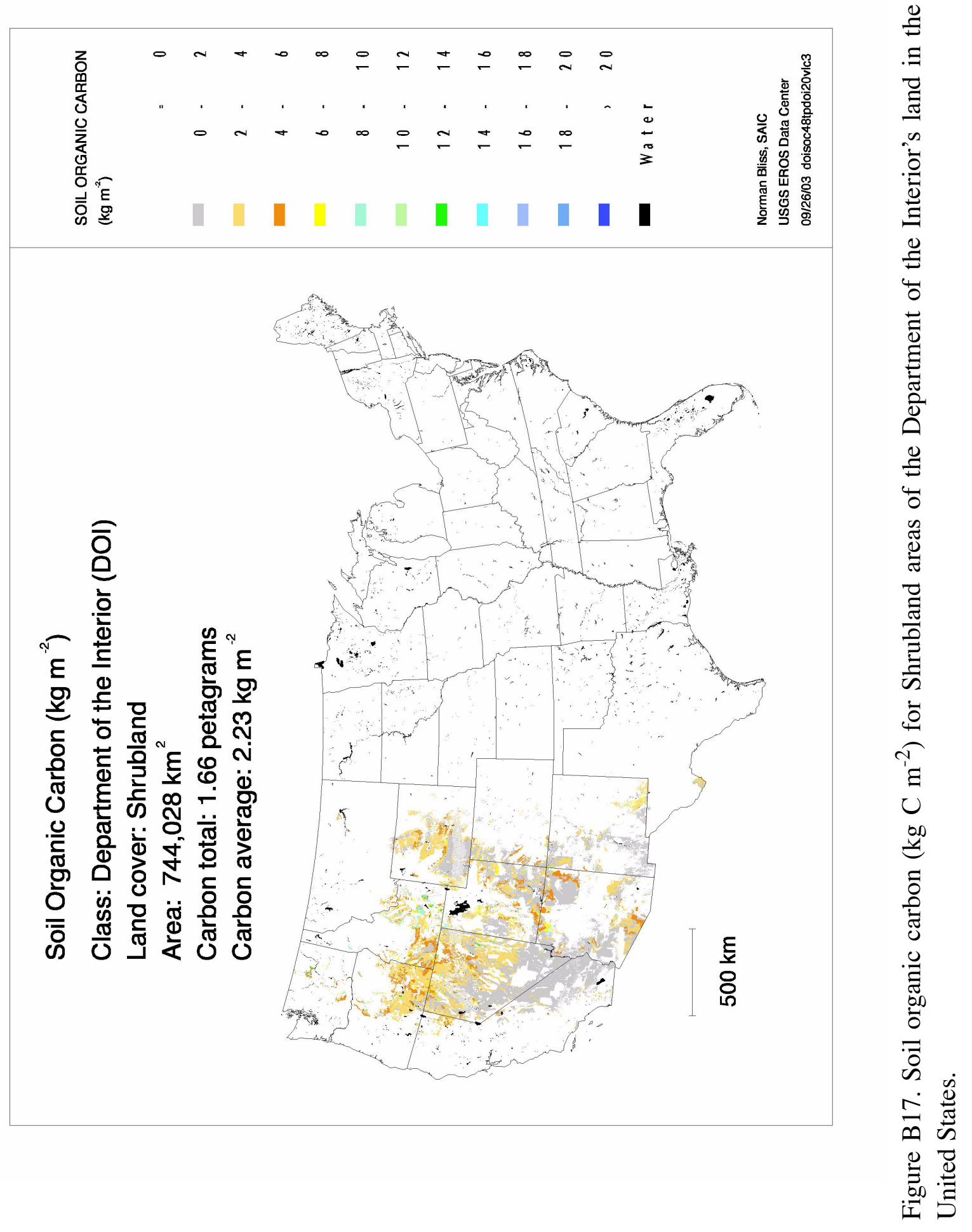



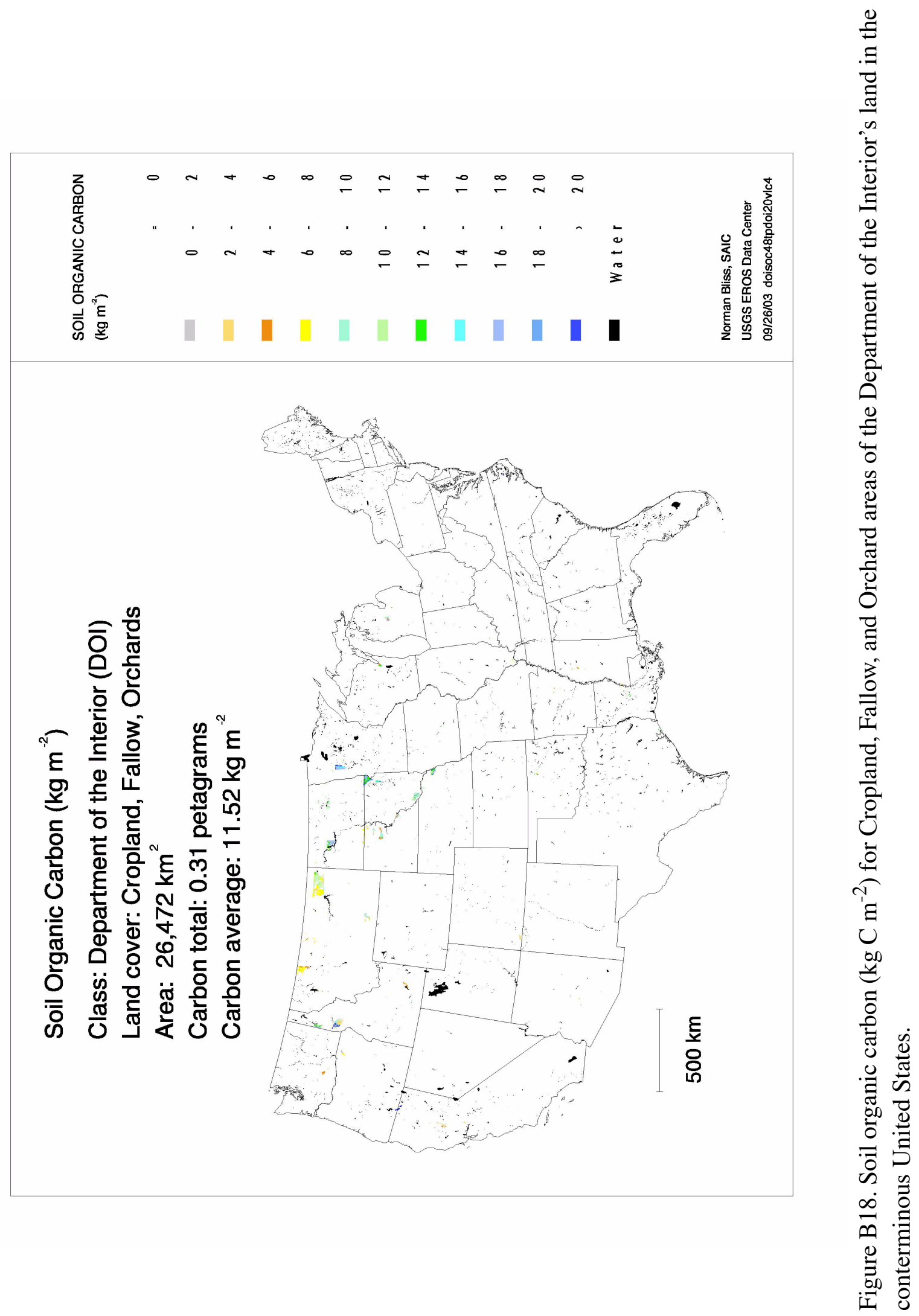

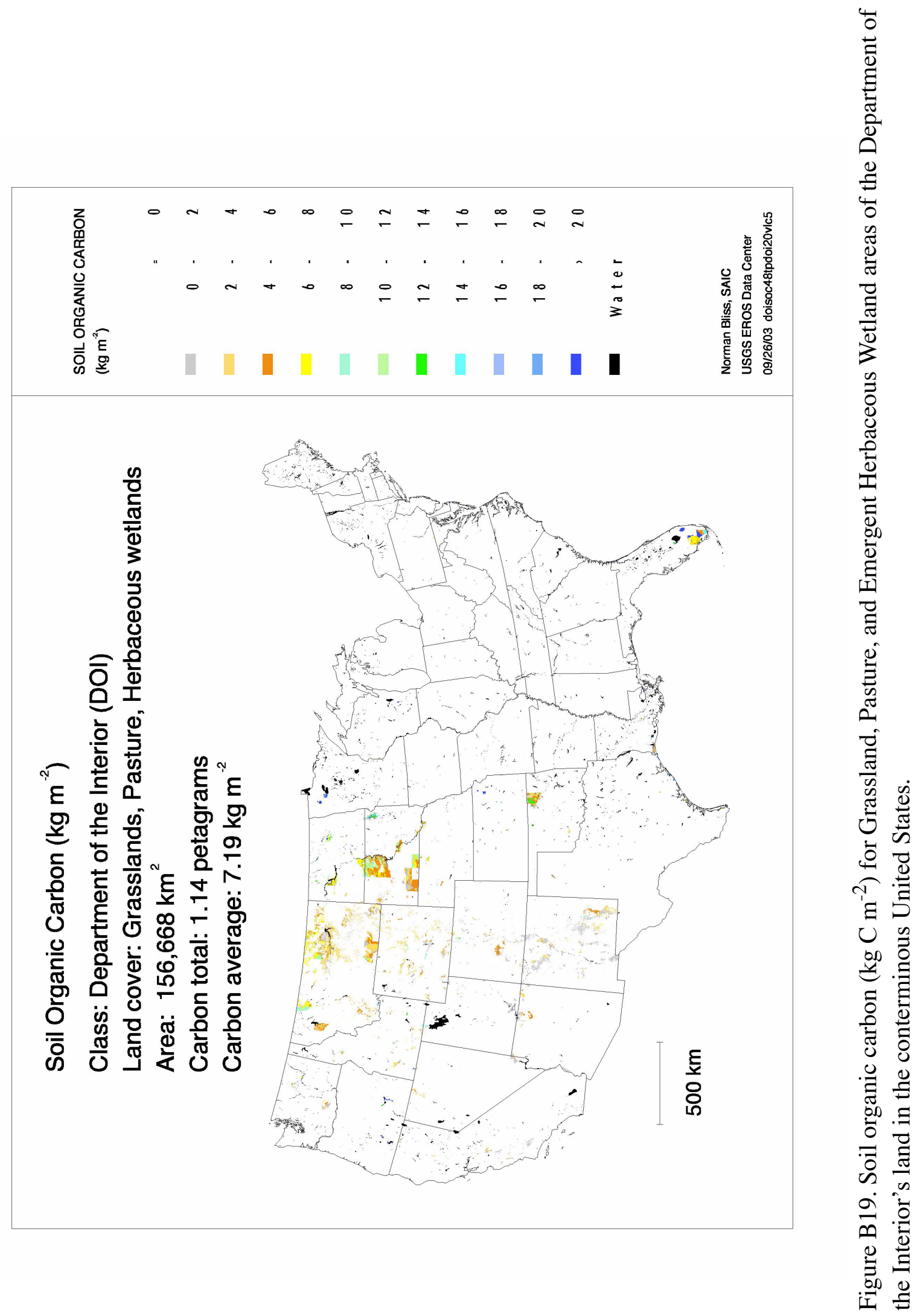


\section{Appendix C: Impact of using dominant land cover class}

If two land cover types are associated with each other on the landscape, one may consistently occur at a higher proportion than the other within a defined region.

Although it does not substantially influence the conclusions about the SOC content of soils on DOI lands, it is possible to document the influence of the use of dominant classes (needed for the maps in figures B13 to B17) in comparison to the statistics generated from the detailed proportions (used in tables 5 through 12).

The land cover dataset was developed by the classification of satellite image data with a pixel size (resolution) of 30 meters. The version of the dataset used in this paper aggregated the 30meter data to $1 \mathrm{~km} \times 1 \mathrm{~km}$ grid cells but retained the proportion of each land cover class from the original data. The calculations reported in the tables used the detailed proportions, and the aggregated statistics accurately reflect the contributions of the minority land cover types within each $1 \mathrm{~km}^{2}$ grid cell.

It would not be convenient to make SOC maps for each minority land cover type associated with each dominant type (and an associated map of the percentage of the grid cell that each such map represents). A large number of maps would be needed to properly represent this complexity, and it would be very difficult to simultaneously interpret such a set of maps.

To create an understandable set of maps, I used the dominant land cover type to subset the DOI lands for the maps shown in figures B13 to B17. The proportion of the grid cell covered by the dominant land cover group (classified according to the grouping in table 3 of the main text) is shown in figure $\mathrm{C} 1$. This map can be used as an aid in interpreting the results shown in figures B13 to B17.

Tables C1 (for area) and C2 (for SOC) represent an aggregation of the data from the detailed proportions of land cover groups within each grid cell (the columns) according to the dominant land cover group (the rows). With these tables, it is possible to observe the extent to which the maps using the dominant land cover group may misrepresent the areas and carbon contents of each land cover group. For example, in map B15 (Shrublands), the area is given as approximately $774,000 \mathrm{~km}^{2}$. From table $\mathrm{C} 1$ we can see that of this area (data row 3, "total" column), only $596,860 \mathrm{~km}^{2}$ (data row 3, data column 3) are actually Shrublands, and there are $74,000 \mathrm{~km}^{2}$ (data row 3, data column 5) of the generalized Grassland class (G5) in the pixels colored on the map.

The potential for misunderstanding is fairly small, because the carbon contents of the grid cells actually shown on each map are accurate according to the methods given in the paper, and the totals for land area and total carbon represent the grid cells present on the map. What is not shown on the maps is the diversity of land cover types that may actually be present within each 1

$\mathrm{km}^{2}$ grid cell. An indication of that diversity is shown in the map in figure $\mathrm{C} 1$, where a high percentage (blue colors) indicates fairly homogeneous grid cells for the given land cover group, and low percentages (green or yellow colors) indicate more diversity or intermixture of the land cover groups on the landscape. 


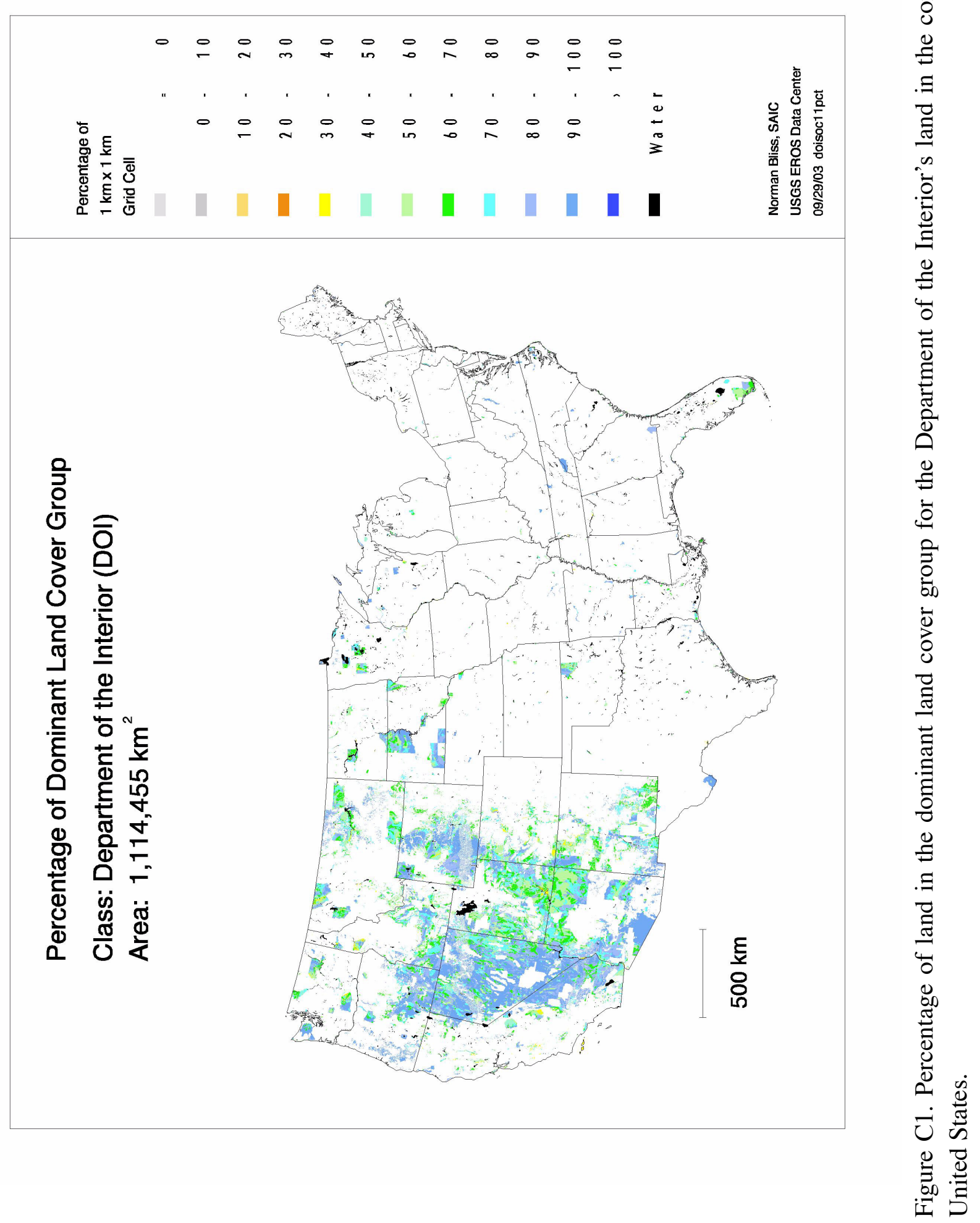




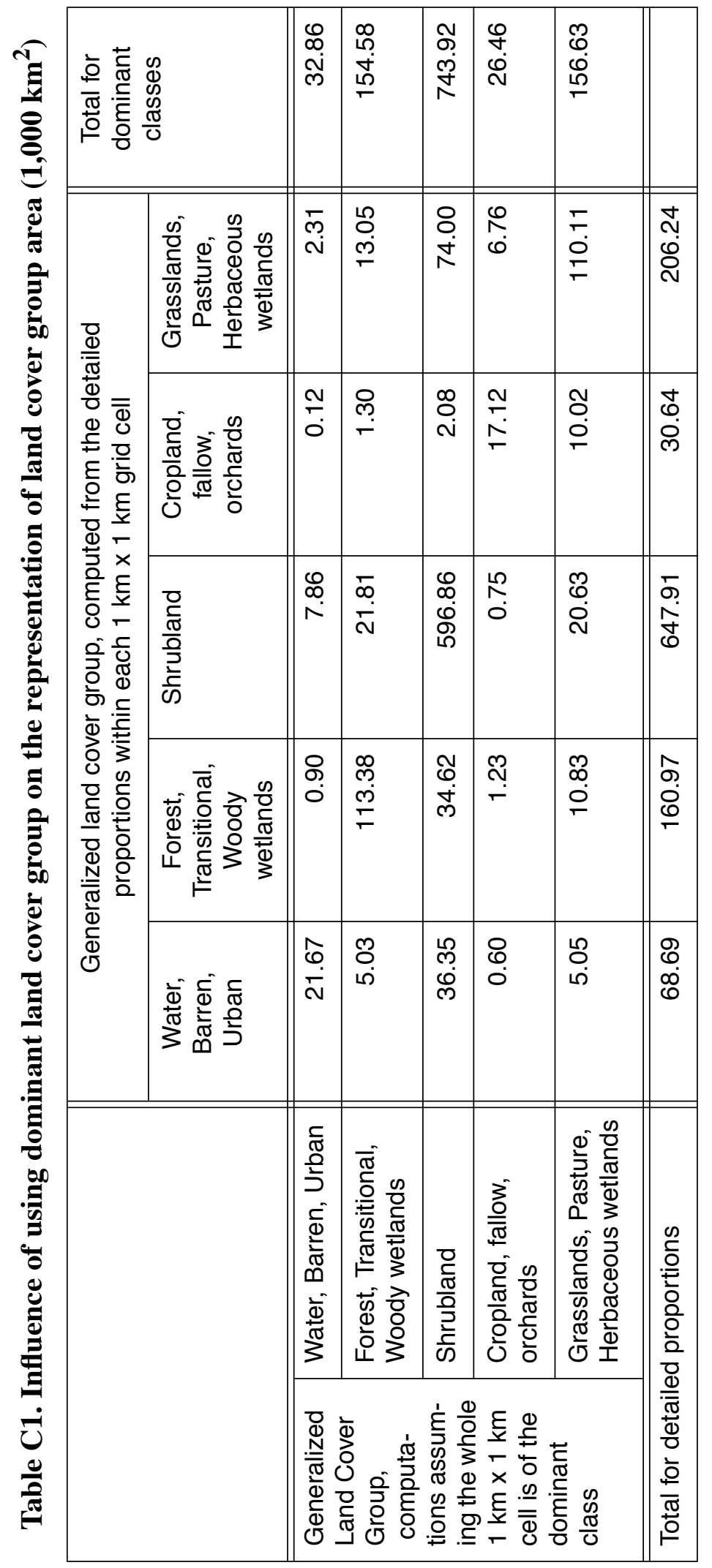




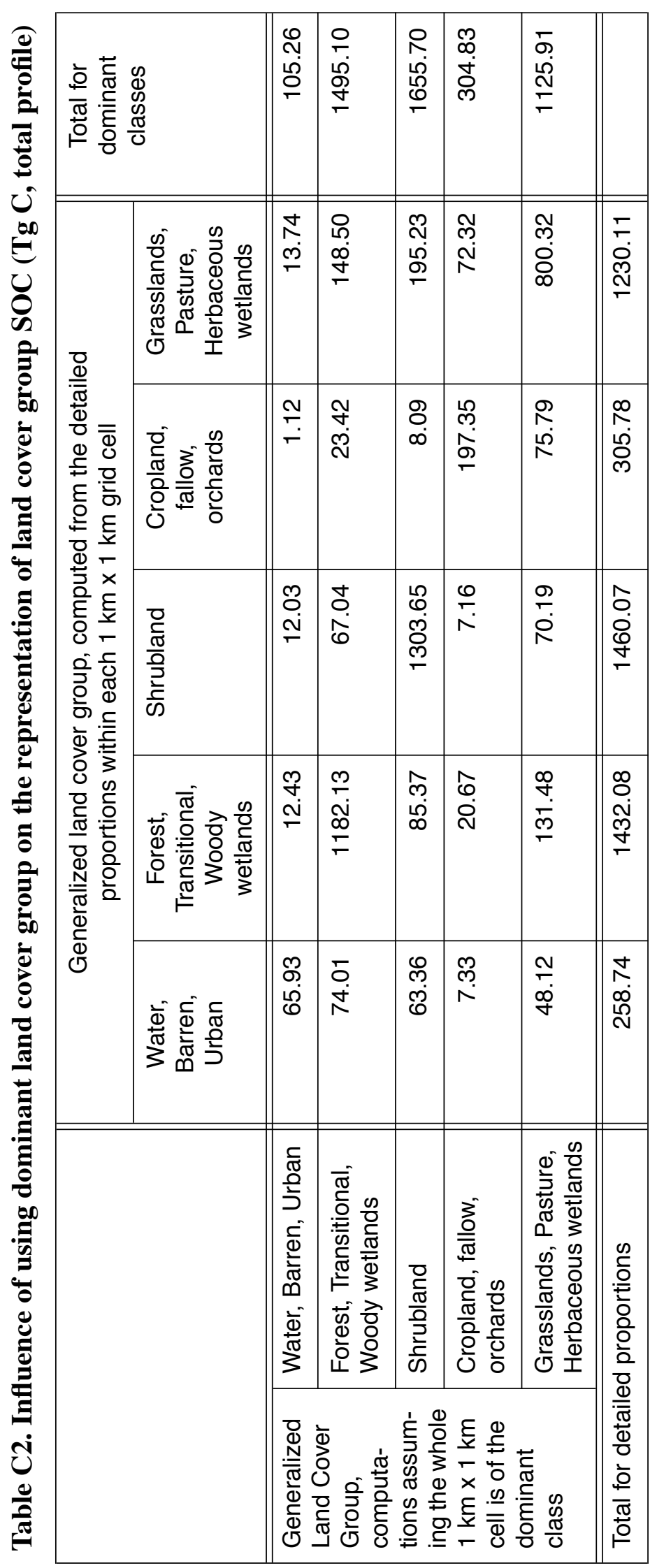

